\title{
Using a gate-to-gate LCA to apply circular economy principles to a food processing
} SME

\author{
Colley, Tracey Anne; Birkved, Morten; Olsen, Stig Irving; Hauschild, Michael Zwicky
}

Published in:

Journal of cleaner production

Link to article, DOI:

10.1016/j.jclepro.2019.119566

Publication date:

2020

Document Version

Peer reviewed version

Link back to DTU Orbit

Citation $(A P A)$ :

Colley, T. A., Birkved, M., Olsen, S. I., \& Hauschild, M. Z. (2020). Using a gate-to-gate LCA to apply circular economy principles to a food processing SME. Journal of cleaner production, 251, [119566].

https://doi.org/10.1016/j.jclepro.2019.119566

\section{General rights}

Copyright and moral rights for the publications made accessible in the public portal are retained by the authors and/or other copyright owners and it is a condition of accessing publications that users recognise and abide by the legal requirements associated with these rights.

- Users may download and print one copy of any publication from the public portal for the purpose of private study or research.

- You may not further distribute the material or use it for any profit-making activity or commercial gain

- You may freely distribute the URL identifying the publication in the public portal 
Please cite this article as: Tracey A. Colley, Morten Birkved, Stig I. Olsen, Michael Z. Hauschild (2020) Using a gate-to-gate LCA to apply circular economy principles to a food processing SME. Journal of Cleaner Production 251, https://doi.org/10.1016/i.jclepro.2019.119566.

Authors: Tracey A. Colley ${ }^{a *}$, Morten Birkved ${ }^{a 1}$, Stig I. Olsen ${ }^{a}$, Michael Z. Hauschild ${ }^{a}$

Author affiliations: a - QSA Division, Management Engineering Department, Technical University of

Denmark (DTU), Kongens Lyngby, 2800, Denmark,

9 Corresponding author (*): trco@dtu.dk / traceycolley@gmail.com, telephone +45 45254886

Abstract:

The purpose of this study was to assess: what are the circular economy opportunities for small and medium-sized enterprises (SME) in the meat processing sector to reduce their environmental impacts, using Life cycle assessment (LCA) as the analytical method to prevent burden shifting; whether current life cycle inventories and LCA studies adequately represent SMEs such as the study plant; and whether climate change is a suitable proxy for impacts.

Life cycle inventory data from a SME meat processing site in regional Australia was used for benchmarking with existing industry data and for risk and opportunity identification along the supply chain. A LCA was conducted of the current operation and possible future energy supply scenarios involving the use of tallow, wastewater methane and biomass production, to identify the best performing option as part of a PhD project on SMEs and sustainability in agribusiness value chains. System expansion was used to handle all coproducts and byproducts. The area of land required to produce biomass was calculated and was compared to the catchment area for livestock, and an estimate was made of the non-arable land area required to produce biomass to offset all greenhouse emissions for the supply chain. Inventory data and LCA results for this SME were significantly different to previous LCAs. The system expansion resulted in large credits, particularly for edible offal. Climate change may not be a suitable proxy for other midpoint impact categories due to the difference in contributing processes. The best future energy was the biomass scenario, which involved using tallow for biodiesel production, capturing methane generated in the onsite wastewater treatment system for electricity generation, using tallow to generate the remaining electricity needs and using biomass for thermal energy production. Less than $0.5 \%$ of the non-arable

\footnotetext{
${ }^{1}$ Current address: Institute of Chemical Engineering, Biotechnology and Environmental Technology (WSR), University of Southern Denmark, Odense, 5230, Denmark.
} 
land area required for producing the livestock for the plant was needed for biomass production, and if all supply chain emissions were offset using biomass, the land area required was $12 \%$ for life time grass fed beef. The potential for supply chain integration in the red meat sector appears promising, particularly in terms of offsets from biomethane use for electricity production, tallow use for biodiesel production and biomass production for thermal energy use. Life cycle assessment is a useful tool to screen circular economy options and identify the best future scenario, although a wide range of impact categories should be assessed as climate change is not a suitable proxy.

Key words (6): environmental sustainability, agribusiness supply chain integration, circular economy, gate-to-gate Life cycle assessment, biomass, non- arable land

\section{Highlights:}

- Optimising use of edible offal is important for reducing impacts of meat production

- Meat processing SMEs may not be adequately represented by current inventory data

- Climate change may not be a suitable proxy for all other mid point impact categories

- Biomass scenario appears to be the best, utilising biogas and tallow for transport biodiesel

- Less than $0.5 \%$ of livestock catchment required to grow biomass

\section{Introduction}

The adverse environmental impacts of meat production, particularly to land-use change, land degradation and climate change, are well documented (Steinfeld et al., 2006). World population growth is expected to increase the amount of food required globally by $70 \%$ by 2050 (FAO, 2012) and more than half of that population growth will occur in Africa (United Nations, 2015). A 2010 study (Leahy et al., 2010) found that only 5\% of the world's 1,525 million vegetarians were vegetarians by choice, the remainder were vegetarians "of necessity" who would start consuming meat as soon as they were financially capable of doing so. Although there is a decrease in the consumption of meat and a growth in rates of vegetarianism and veganism in middle and high income countries due to a combination of health, environmental and animal welfare concerns, the growth of meat consumption in other countries will offset this, leading to a net increase in livestock related methane emissions (Leahy et al., 2010). Australia is a net exporter of red meat and for the 2016 calendar year exports included $70 \%$ of the national beef production $(1,018,105$ tonnes), $56 \%$ of the lamb production (242,285 tonnes), $95 \%$ of the mutton production $(132,199$ tonnes) and almost all of the goat production (26,794 tonnes) (Meat \& Livestock Australia, 2018).

Recent Australian data indicates that $52 \%$ of the land area of Australia is used for agriculture, and of this land, only $7 \%$ is used for growing crops, including hay and silage (Australian Bureau of Statistics, 2017).. Current climate change projections indicate that there will be increases in temperatures 
(mean, daily minimum and maximum), potential evapotranspiration, the frequency and severity of hot days and extreme rainfall events, the duration of droughts and the frequency of extreme droughts in southern Australia, and there will be decreases in the amount of winter and spring rainfall in southern Australia (CSIRO and Bureau of Meteorology, 2015). The changes vary by geographic region but are expected to reduce the quality and quantity of agricultural produce (Reyenga, Howden, Meinke, \& Hall, 2001), make production less reliable (Stokes et al., 2008), and increase animal and plant heat stress (Australian Government Department of Agriculture and Water Resources, 2018; Nardone et al., 2010). The net impact will be that the suitability of regions to their current agricultural produce will change, as the increasing frequency of soil-moisture based droughts will lead to a net reduction in the availability of arable land as it transitions to non-arable agricultural production (Mpelasoka et al., 2008).

Life cycle assessment (LCA) has been used to analyse the environmental impacts of meat supply chains, usually focusing on a limited number of midpoint impact categories (MIC) such as carbon or water footprints. A comprehensive review of livestock production (Cederberg et al., 2012) found that almost all studies analyse the global warming impact category, most studies analyse energy use and acidification, eutrophication and land use impact categories and some studies analyse toxicity, resource depletion and water use Land use indicators have generally not included any consideration of land quality, so have not differentiated between prime arable land and non-arable or more marginal land. Most of the studies of climate change do not include changes to soil carbon or land use change (direct or indirect).

A recent review of LCA studies in Australian chicken, pork, lamb and beef meat supply chains (Wiedemann, 2018) highlighted that the system boundary of most LCA studies end at the farm gate, so only a limited number of studies investigate impacts from processing and transport. Midpoint impact categories covered in all studies relate to the issues most relevant to the Australian context, namely climate change (but often omitting emissions relating to land use, direct land use change and soil carbon), energy use, water use (consumptive and stressed) and in more recent studies, land use (total, arable and non-arable). Nutrient cycles or biodiversity have not been directly addressed even though recent research (Rockström et al., 2009) indicated that their planetary boundaries have been or are close to exceedance. Foreground data used in the life cycle inventories included primary data from SME farms and meat processing plants, as well as more generic industry survey data. Studies used a variety of different methods to handle coproducts and byproducts, ranging from system expansion (tallow replaced by rape seed oil or palm oil, meal replaced by soymeal or sorghum) to allocation, both economic and physical (both mass and biophysical based on energy and protein 
content). A detailed review of LCA studies which include meat processing is included in Supplementary Material 1 (SM1) and emissions and consumption relating to the meat processing stage for Australian LCAs indicate that fossil fuel energy use in meat processing ranges from $14 \%$ in the pork case through to $67 \%$ in a beef study (Gregory M. Peters et al., 2010) for the full life cycle, with higher overall consumption in grain fed beef compared to lifetime grass fed. Only a small portion of total supply chain fresh water consumption (2-6\%) and greenhouse gas emissions (4-14\%) occurs at the meat processing stage.

Recent European Environmental Product Declarations (COOP, 2016a, 2016b; Inalca, 2018; INALCA, 2018 ) indicate that core processes (meat processing plant and transport of all raw materials to the plant) contribute a small amount of the total environmental impact per kilogram of boneless meat, ranging from $8-12 \%$ for greenhouse gas potential (1.7-2.7 $\left.\mathrm{kg} \mathrm{CO}_{2-\mathrm{e}}\right), 9-12 \%$ for eutrophication potential (0.5-0.7 $\mathrm{g} \mathrm{PO}_{4}{ }^{3-}-$ e), 1-2\% for ozone creating potential (5.3-7.5 $\mathrm{g} \mathrm{C}_{2} \mathrm{H}_{4-\mathrm{e}}$ ) and $1 \%$ for acidification potential ( $\left.\mathrm{g} \mathrm{SO}_{2-\mathrm{e}}\right)$.

LCA and other studies aimed at identifying improvements in the sustainability of meat supply chains have focused on single life cycle stages, then aggregated the opportunities from individual stages to propose a whole of supply chain approach (i.e. an additive approach) (Mayberry et al., 2018; Peters et al., 2009; Wiedemann et al., 2014). Only more recently have LCA studies taken a whole of supply chain approach (Hessle et al., 2017; Notarnicola et al., 2017; Paolotti et al., 2016; Sonesson et al., 2016), identifying opportunities within and between life cycle stages and interconnected supply chains, to optimise the whole supply chain, rather than just individual portions of it (i.e. a synergistic approach). This is more in line with circular economy principles, which are: Principle 1 - the value of products, coproducts and byproducts are to be maximised at all stages in the supply chain and between supply chains, with the overall aim of maintaining inputs and products at their highest utility at all times; Principal 2 - Natural capital is to be preserved and enhanced by replacing finite stocks with renewable resources; and Principle 3 - system effectiveness is to be fostered by identifying and eliminating negative externalities such as waste and pollution (Ellen MacArthur Foundation, 2015; Stahel, 2016). At present the circular economy is depicted as being very consumer-centric, but this study will investigate the potential between the core processing stage in the supply chain (meat processing) with the upstream on-farm production, and the linking transport stages, as indicated by the red arrows in Figure 1. 


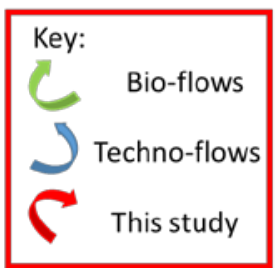

\section{(n)ent)} (renewable flow management)

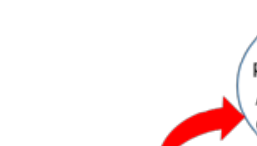
Primary production extraction extraction 西 Technical / Mineral Cycle (stock management)

Figure 1: Circular economy of this study (adapted from (Ellen MacArthur Foundation et al., 2015)).

Q fever, caused by the bacteria Coxiella burnetii, is one potential constraint on applying circular economy principles within meat supply chains since if it is present in animals entering the plant it may survive the wastewater treatment system and may then be present in treated wastewater which is available for nutrient recycling. The bacteria is extremely resistant to heat, drying and chemical agents (such as disinfectants), can survive in the environment for long periods of time (Shishido et al., 2016) and is highly infectious, requiring less than 10 bacteria to cause an infection (Center For Disease Control, 2012). It causes cases of illness in the meat industry (Gidding et al., 2009; Lowbridge et al., 2012; Tissot-Dupont et al., 2004) and the wider population (Dahlgren et al., 2015b; Eastwood et al., 2018; O'CONNOR et al., 2015; Sivabalan et al., 2017; Tozer et al., 2011; Whitney et al., 2009), with symptoms similar to influenza even though a small percentage have more severe symptoms (Anderson et al., 2005; Dahlgren et al., 2015a; Nourse et al., 2004).

The definition of a small and medium-sized enterprise varies, but in this study a SME is defined as having less than 250 employees, to be consistent with the OECD definition (OECD, 2005). The study site is representative of SMEs in the meat processing sector in regional Australia. In a recent environmental benchmarking report (Ridoutt et al., 2015) 14 red meat processing facilities, which did not include the current study site, were assessed of the 150 plants operating in Australia (i.e. 9\%) and the assessed plants produced $34 \%$ of the total production for the year of the study (2012/2014), meaning that the study was dominated by non-SME plants. This study was intended to assist the site, a SME, with identifying where it could most significantly improve its environmental performance while simultaneously addressing business costs and risk issues. The research questions 
therefore were: 1) do current life cycle inventories and LCA studies adequately represent SMEs in this sector such as this plant; 2) what are the circular economy opportunities for SME regional meat processors to reduce their environmental impacts, using LCA as the analytical tool to prevent burden shifting; and 3) is climate change a suitable proxy for other impact categories.

\section{Material and Methods}

2.1 System Description

This study focuses on a gate-to-gate life cycle assessment of a domestic meat processing plant which processes lamb, sheep, veal, beef, pork and goats and is representative of smaller plant with rendering serving the domestic "kill and chill" market in regional areas, using a more comprehensive inventory than previous studies. The site does not include freezing, so the onsite heating ventilation and air conditioning services (HVAC) are provided by individual packaged refrigeration units using hydrofluorocarbon and hydrochlorofluorocarbons, rather than the centralised ammonia systems. The functional unit was 1 tonne of hot standard carcass weight (HSCW) at the retailer, as the plant sells whole carcasses, sides, primal cuts and has its own retail ready product lines (New England Lamb and Macleay River Veal). The system boundaries cover the core processes at the processing plant, including onsite activities and wastewater treatment, transport of inputs to the processing plant and the transport of products to market, which is controlled by the processing plant owner, as outlined in Figure 2.

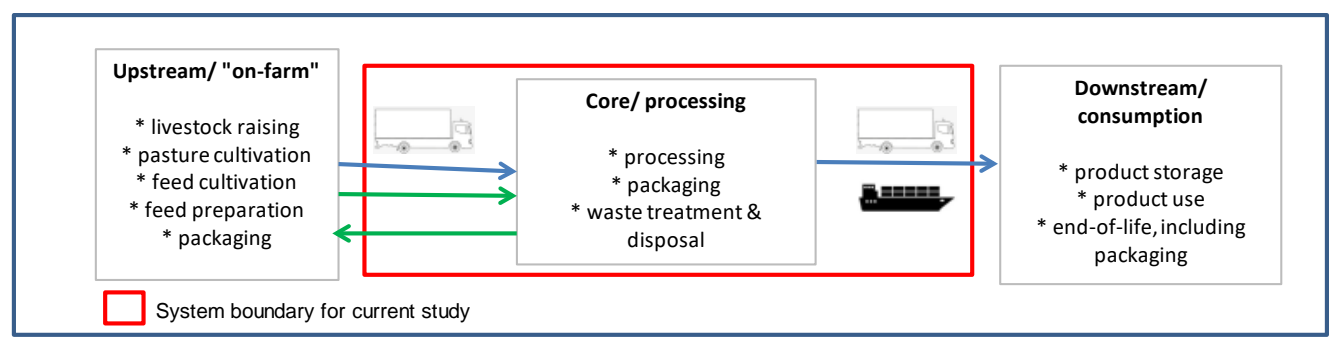

Figure 2: System boundaries for current study - livestock production system for cattle, sheep, goats and pigs

The SME study site was located in the Mid North Coast region of New South Wales, an area of 18,851 square kilometres, $52 \%$ of which is agricultural land including $27 \%$ which is used for grazing on modified pastures (Department of Agriculture and Water Resources, 2017). Beef cattle and dairy farms account for $59 \%$ and $16 \%$ of all farms respectively (Australian Bureau of Statistics, 2018). A recent Australia wide review of native vegetation management on agricultural land found that the percentage of native vegetation on farms ranged from a low of $3 \%$ on dairy farms, to $11 \%$ for specialised sheep and mixed cropping-livestock farm, $14 \%$ on sheep-beef farms and $30 \%$ on specialised beef farms (Harris-Adams et al., 2012). Linear easements, such as rail, road and 
powerline corridors, occupy $6.5 \%$ of the land area of New South Wales, which is not insignificant when compared to the $8 \%$ of land area preserved within National Parks and Nature Reserves (Dufty, 2010).

2.2 Inventory data, benchmarking, risks and opportunities

Primary data was collected from the processing site for the 2015-2016 financial year for inputs such as livestock, energy (electricity, boiler fuels, transport fuels), water, chemicals (boiler, pest control, skins treating), products (meat), coproducts (edible offal), byproducts (not edible for humans but have a current use, such as tallow, meal, skins, paunch, manure, boiler ash, treated effluent) and wastes (no current economic use such as wastewater methane). Production data for meat, tallow and meal was obtained and based on the mix of species entering the plant, it was calculated that the average yield from live weight to HSCW was $50 \%$. As the study site is an integrated plant, an onsite rendering plant converts byproducts from meat processing and waste from local butchers and boning rooms into tallow and meal. A detailed inventory is provided in SM2.1.

This primary life cycle inventory data was benchmarked against existing metrics for the red meat processing industry and the relative energy costs were ranked, to assist with identifying priorities for substitution. An energy balance of the site was undertaken to identify the current consumption and production of energy and to identify the reuse potential of coproducts, byproducts or wastes.

Secondary data from literature was used for inputs sourced from multiple suppliers such as packaging and chemicals (lube oil, cleaning, wastewater treatment) (Pagan et al., 2002). The site refrigeration system uses individual packaged units rather than a centralised ammonia or glycol system, so estimates of refrigerant losses were included based on the installed capacity, estimated refrigerant charge of $1.5 \mathrm{~kg} / \mathrm{kW}$ load and an estimated annual leakage rate of $10 \%$ for a medium temperature distributed system (Emerson Climate Technologies, 2010a). The theoretical maximum pond methane emissions were calculated using production data and the default values for meat processing in the methodology specified by the Australian Federal Government (Department of the Environment and Energy, 2016a). Transport fuel consumption for most site inputs was estimated based on the weight and transport distances $(450 \mathrm{~km}$ from the port of Brisbane to the regional hub at Coffs Harbour and $150 \mathrm{~km}$ from the regional hub to the site for most inputs, with 1,800 km for salt for skins treating, $900 \mathrm{~km}$ for skin preservative and $450 \mathrm{~km}$ for boiler coal). A commercial database (Ecoinvent 3.2) was used for background processes and some processes, such as the average diesel consumption in truck transport, were modified for Australian fleet averages $(0.028 \mathrm{~L} / \mathrm{tkm}$ for articulated trucks and $0.076 \mathrm{~L} / \mathrm{tkm}$ for rigid/other trucks (Australian Bureau of Statistics, 2015). The 
210

211

212

213

214

215

216

217

218

219

220

221

222

223

224

225

226

227

228

229

230

231

232

233

234

235

236

237

238

239

240

241

fuel consumption in the site-owned transport fleet that delivers products to customers was converted to a tkm equivalent by dividing the litres of diesel consumed per functional unit by the average fuel consumption per $\mathrm{tkm}$, assuming that $50 \%$ of the product was delivered by rigid trucks and $50 \%$ by articulated trucks, then modelled using a modified Ecoinvent processes. Previous LCA studies were used to provide information on the area of arable and non-arable land used for upstream sheep and beef production (Wiedemann et al., 2016, 2015a) for biomass production.

A qualitative review of risks and opportunities in the supply chain was undertaken, with a particular focus on risks with catastrophic consequences (SAI Global, 1999), which could lead to an offsite impact such as the death of a member of the public, a toxic release with detrimental effects or significant financial loss. Information on risks was obtained from site specific data (NSW Environment Protection Authority, 2015), generic industry data (Dames \& Moore Pty Ltd, 1999; Office of Environment \& Heritage, 2011; Sloan-Gardner et al., 2017; URS Australia Pty Ltd, 2006) and compliance review information from the regulator (NSW Environment Protection Authority, 2010, $2009,2003)$. The review of opportunities focused on the potential for supply chain integration in the surrounding geographic area and the potential to contribute positively to issues such as biodiversity, animal welfare and local employment, using the three circular economy principles. Opportunities were limited to widely available, proven technologies, due to the regional location of the plant (and subsequent limitation on the availability of skilled specialists) and the risk averse nature of the industry.

The locational benefits of the site (i.e. regional location and surrounding land use) and current operation were assessed in a qualitative fashion, to match potential synergies with identified risks, such as the beneficial reuse of treated effluent.

2.3 Life Cycle Impact Assessment - methods and modelling

Given that the goal was consistent with situation A "micro-level decision support" with no change in production levels, attributional datasets were used (EC-JRC, 2010). Previous LCAs had used a hybrid approach for handling coproducts and byproducts, using a combination of system expansion and by allocation (economic, physical or both). For this study, system expansion was used for handling all coproducts and byproducts. The main substituted products for tallow were palm oil and rape seed oil (on a mass basis), polyester for hides (on a mass basis), rape meal for meal (on a mass basis) and an upstream substitution of market for edible offal (upstream substitution of market for cattle for slaughtering on a mass basis). Other system expansions included natural aggregate for boiler ash on a mass basis, market for soil conditioner for manure and paunch on a mass basis, and the market for 
irrigation for wastewater irrigation volumes on a volume basis. For the biomass case, the nutrient content of the wastewater was assumed to replace commercial fertilisers.

The life cycle impact assessment methods and 12 midpoint impact categories (MIC) recommended in the Best Practice Guide by the Australian Life Cycle Assessment Society (ALCAS) were used (Renouf et al., 2016), namely: climate change ( $\left.\mathrm{kg} \mathrm{CO}_{2 \text {-eq }}\right)$; minerals resource depletion ( $\left.\mathrm{Sb}_{\text {-eq }}\right)$; fossil fuels resource depletion (MJ); consumptive water use $\left(\mathrm{m}^{3} \mathrm{H}_{2} \mathrm{O}_{- \text {eq }}\right)$; eutrophication ( $\mathrm{kg} \mathrm{PO}_{4}{ }^{3-}$-eq); acidification ( $\left.\mathrm{kg} \mathrm{SO}_{2-\mathrm{eq}}\right)$; human toxicity $\left(\mathrm{CTU}_{\mathrm{h}}\right)$; ecotoxicity $\left(\mathrm{CTU}_{\mathrm{e}}\right)$; photochemical ozone formation $\left(\mathrm{C}_{2} \mathrm{H}_{4 \text {-eq }}\right)$; particulate matter formation ( $\left.\mathrm{kg} \mathrm{PM}_{2.5 \text {-eq }}\right)$; ozone depletion (kg CFC-11-eq); and ionizing radiation ( $\mathrm{kBq}$ U235-eq). The characterisation factors used were from version 2 of the best practice guide (Renouf et al., 2016) except for human toxicity and ecotoxicity, which used USEtox, the default method in openLCA. Three ReCiPe (H) endpoint (damage) impact categories (EIC) (human health, ecosystems and resources) were also used, as was agricultural land use using the ReCiPe $(H)$ method. LCA modelling used openLCA software (version 1.7).

2.4 Scenarios - LCA modelling, land use balance

The reference scenario (REF) was based on the current operation. A number of electricity efficiency projects had been identified at the site and it is assumed that these were implemented, thus reducing the baseline energy consumption compared to the collected data for the REF case in the efficiency scenario (EFF). The efficiency projects were combined with electricity from solar photovoltaics and a small wind turbine.

Alternative energy supply scenarios were developed, particularly opportunities to integrate with upstream (farming) and downstream (retail/consumer). Options considered were the use of tallow (TAL), the use of biogas from anaerobic wastewater treatment ponds (BGS) and the use of biomass (BMS). When tallow was converted to biodiesel, it was assumed that the glycerine produced was discharged into the onsite wastewater treatment pond system in the BGS and BMS scenarios to increase methane generation, whereas in the TAL scenario it was handled via system expansion. Inventory data for tallow biodiesel production was taken from (Dufour and Iribarren, 2012), from (Poeschl et al., 2012) for biogas upgrading and from (Yanagida et al., 2011) for biomass production. The details of these scenarios are outlined in Table 1 . The results for the scenarios were internally normalised by dividing by the "best" result in each impact category, so the value 1 represents the best environmental outcome. 


\begin{tabular}{|l|l|}
\hline Scenario & Details \\
\hline $\begin{array}{l}\text { Reference } \\
\text { (REF) }\end{array}$ & Current operation \\
\hline Efficiency (EFF) & $\begin{array}{l}\text { (14\% reduction in electricity consumption) + (15kW of solar photovoltaics } \\
\text { electricity generation) + (25 kW of wind electricity generation) }\end{array}$ \\
\hline Tallow (TAL) & $\begin{array}{l}\text { EFF + (tallow used for electricity generation, site transport fleet (biodiesel) and } \\
\text { part of thermal energy) + (residual of thermal energy from current fuel source) }\end{array}$ \\
\hline Biogas (BGS) & $\begin{array}{l}\text { EFF + (biogas used for electricity generation) + (tallow used for residual } \\
\text { electricity generation + biodiesel for site transport fleet + all thermal energy) }\end{array}$ \\
\hline Biomass (BMS) & $\begin{array}{l}\text { EFF + (biogas for electricity generation) + (residual electricity generation from } \\
\text { tallow) + (tallow used for site transport fleet diesel consumption) + (biomass for } \\
\text { all thermal energy) + residual tallow sold }\end{array}$ \\
\hline
\end{tabular}

273

274

A land use balance was conducted to assess the area of land required for biomass production for 2 cases; 1) using non agricultural land and 2) comparing non-arable land required to produce livestock for the plant and the area of land required to produce sufficient biomass for the plant thermal energy requirement. Only non-arable land use associated with livestock production was used, as insufficient data was available on goat and pork production. Biomass production per hectare was assumed to be $30 \mathrm{~m}^{3} /$ ha/year (Heathcote, 2002) with a density of $265 \mathrm{~kg} / \mathrm{m}^{3}$ (Thomas et al., 2009) and the energy content was assumed to be $10.4 \mathrm{GJ} / \mathrm{t}$ (Department of the Environment and Energy, 2016a), providing a gross energy production of $83 \mathrm{GJ} / \mathrm{ha} /$ year.

\section{Results and Discussion}

\subsection{Life Cycle Inventory benchmarking, risks \& opportunities}

As indicated in Table 2, the site consumed a significantly lower volume of water compared to the Australian industry benchmarking data, by ratios of $0.28-0.34$, and the nitrogen and phosphorus emission levels were lower than industry averages but not as significantly, with average ratios of 0.55 and 0.75 respectively. The water consumption values are consistent with Australian industry data, as significant amounts of water are used in the boning room and this plant only processes a small percentage of the carcases, which highlights the difference between domestic SME and larger export plants (Pagan et al., 2002). The difference between the Australian industry and overseas industry figures from COOP Environmental Product Declarations (EPDs) (e and f) may reflect the importance that has been placed on reducing water consumption in Australia due to scarcity issues. The nutrient levels are consistent with research on the source of nutrients and organic load within 
294

295

296

297

298

299

300

301

302

303

304

meat processing plants, which indicates that the paunch processing and rendering plants contribute the greatest nutrient load, whereas boning rooms contribute only a very small proportion of the wastewater nutrient load (Jensen and Batstone, 2012).

For electricity consumption, the plant consumed 0.4 of the industry average. This is consistent with SME "kill and chill" domestic plants, which chill but do not freeze product. Thermal energy use and total energy use were about the same as the average industry consumption in terms of the total amount. This is consistent with industry data, as thermal energy use is normally over $70 \%$ of total site stationery energy use, and the rendering plant is normally the largest thermal energy consumer (Hydro Tasmania Consulting, 2009). It may also indicate inefficiency in the thermal energy system, ranging from generation, distribution or end use efficiency.

Table 2: Life Cycle Inventory data benchmarked against published meat processing industry data

\begin{tabular}{|c|c|c|c|}
\hline Parameter & Site value & Industry & $\begin{array}{l}\text { Site: Industry } \\
\text { ratio }\end{array}$ \\
\hline Water use (kL/t HSCW) & 3.0 & $\begin{array}{c}6-9^{a} \\
8.9^{b} \\
9.4^{b} \\
10.6^{d} \\
43^{e} \\
33^{f}\end{array}$ & $\begin{array}{c}0.33-0.5 \\
0.34 \\
0.32 \\
0.28 \\
0.07 \\
0.09\end{array}$ \\
\hline Wastewater Nitrogen release (kg N/ t HSCW) & 0.95 & $\begin{array}{l}1.5^{\mathrm{c}} \\
2.1^{\mathrm{d}}\end{array}$ & $\begin{array}{l}0.6 \\
0.5\end{array}$ \\
\hline Wastewater Phosphorus release (kg P/ t HSCW) & 0.20 & $\begin{array}{l}0.25^{c} \\
0.3^{d}\end{array}$ & $\begin{array}{l}0.8 \\
0.7\end{array}$ \\
\hline Electricity use (kWh/ t HSCW) & 105 & $\begin{array}{l}271^{g} \\
280^{h}\end{array}$ & $\begin{array}{l}0.4 \\
0.4\end{array}$ \\
\hline Thermal energy use (MJ/t HSCW) & 2,739 & $2,391^{f}$ & 1.1 \\
\hline $\begin{array}{l}\text { Total energy use (MJ/t HSCW) } \\
\text { (note - excludes transport) }\end{array}$ & 3,117 & $\begin{array}{l}3,005^{b} \\
4,108^{c} \\
3,389^{d} \\
3,368^{g}\end{array}$ & $\begin{array}{l}1.0 \\
0.8 \\
0.9 \\
0.9\end{array}$ \\
\hline
\end{tabular}
2005), e - (COOP, 2016b) core processes for veal only, corrected for $75 \%$ boneless meat yield, $f$ - 
307 (COOP, 2016a), core processes for beef only, corrected for $80 \%$ boneless meat yield, $\mathbf{g}$ - (Hydro

308 Tasmania Consulting, 2009), h - (Rowlands et al., 2007).

309 Transport energy consumption added over $30 \%$ to the total site total energy use, bringing it up to

$3104,701 \mathrm{MJ}$ per tonne of HSCW, as indicated in Table 3. Significant energy is available from coproducts

311 and waste, with nearly 5,000 MJ/t HSCW from tallow and 1,000 MJ/t HSCW from biogas from the

312 onsite anaerobic wastewater treatment ponds. If the efficiency of generation (assumed to be 39\%

313 (GE Power, 2016)) was factored into the electricity consumption figure, this would give energy

314 consumption of $969 \mathrm{MJ}$ for the electricity generation and a total site consumption of 5,293 MJ/t

315 HSCW.

316 In terms of costs per MJ, if electricity is ranked as a value of 1 , then diesel is 0.5 (or $50 \%$ of the cost

317 of electricity) and coal (the main boiler fuel) is 0.1 (or $10 \%$ of the cost of electricity). This is consistent

318 with industry data (Hydro Tasmania Consulting, 2009).

319 Table 3: Site Energy Balance and Cost Ratios

\begin{tabular}{|l|c|c|c|}
\hline Site Energy Balance & $\begin{array}{c}\text { Use } \\
\text { (MJ/t HSCW) }\end{array}$ & $\begin{array}{c}\text { Availability } \\
\text { (MJ/t HSCW) }\end{array}$ & Cost ratio \\
\hline Electricity & 378 & & 1 \\
\hline Thermal Energy (boiler etc.) & 2,739 & & Coal: 0.1 \\
\hline Transport Energy & 1,585 & & Diesel: \\
\hline Total usage & & & 0.5 \\
\hline Total usage (corrected for efficiency of electricity & 5,293 & & \\
\hline production) & & & \\
\hline Tallow ${ }^{\text {a }}$ & & 4,793 & \\
\hline Biomethane from anaerobic ponds ${ }^{b}$ & & 926 & \\
\hline Total availability & & 5,720 & \\
\hline
\end{tabular}

321 b) maximum theoretical amount based on NGER default values of $13.7 \mathrm{~kL}$ wastewater/t HSCW, 6.1 kg COD/kL wastewater,

3220.8 fraction conversion of COD to methane, $6.3 \mathrm{t} \mathrm{CO}_{2 \text {-eq }}$ biomethane $/ \mathrm{t} \mathrm{COD} \mathrm{removed,} 25 \mathrm{t} \mathrm{CO}$-eq $/ \mathrm{t}$ methane, $0.6784 \mathrm{~kg}$

323 methane $/ \mathrm{m}^{3}$ methane and $37.3 \mathrm{MJ} / \mathrm{m}^{3}$ biomethane (Australian Government Clean Energy Regulator, 2018; Department of

324 the Environment and Energy, 2016b).

325 As indicated in Table 4, the two major risks relate to the interruption to electricity supply to the site

326 and the potential risk that $Q$ fever may be entering the plant, surviving through the wastewater

327 treatment system and therefore be present in the treated effluent. The major opportunities relate to 
converting tallow into biodiesel to replace fossil diesel in the company transport fleet, capturing and using biogas from the anaerobic wastewater treatment pond and engaging with upstream farmers in the local area for on-farm coproduction of biomass.

Table 4: Summary of risks, opportunities and circular economy opportunities.

\begin{tabular}{|l|c|c|c|}
\hline \multirow{2}{*}{ Risk } & $\begin{array}{c}\text { Upstream (on-farm } \\
\text { primary production) }\end{array}$ & $\begin{array}{c}\text { Core } \\
\text { (processing) }\end{array}$ & $\begin{array}{c}\text { Downstream (use \& } \\
\text { end of life) }\end{array}$ \\
\hline \multirow{2}{*}{ Opportunity } & Q fever in animals & Q fever in wastewater & \\
\cline { 2 - 4 } & & Interruption to electricity supply & \\
\cline { 2 - 4 } & Fertiliser use on farm & Nutrient content in treated effluent ${ }^{1,2}$ & \\
\cline { 2 - 4 } & Transport fuel use & Tallow conversion to biodiesel ${ }^{1,2}$ & Transport fuel use $^{2}$ \\
\cline { 2 - 4 } & Biomass production & Biomass use for electrical/thermal energy ${ }^{2}$ & \\
\hline
\end{tabular}

Notes: 1 - Circular economy principle 1 - value maximised at all times; 2 - Circular economy principle 2 - preserve natural capital and replace with renewables; Circular economy principles 3 eliminate waste and pollution.

Given the alignment between the cost ratios and identified risks, finding an alternative source of electricity is the most significant opportunity. From a cost and opportunity perspective, replacing purchased diesel in the site transport fleet with biodiesel produced from tallow should be the next highest priority, with replacement of thermal fuel as a lower priority. Although the treated effluent contains valuable nutrients which could be recycled to on-farm primary production, care should be taken to ensure that it is used in applications which will not cause a risk to animals, so use in dairy farming applications such as pasture fertilisation should be avoided in favour of using the treated effluent for biomass production.

\subsection{LCA of Current site operation}

LCA results for the reference scenario and previous LCA and EPD studies are presented in Table 5 for the MIC assessed. Compared to the values reported in existing LCA studies from Australia, the climate change value is consistent with previous LCA studies (Gregory M. Peters et al., 2010; Wiedemann et al., 2015a). The fossil fuel use is substantially lower, which is significant given that in previous LCA studies, this life cycle stage contributed from $14-67 \%$ of total fossil fuel use. This is consistent with the life cycle inventory, where the electricity use was significantly lower than published industry averages. The difference between the fossil fuel use and climate change values may be due to non-fossil sources, such as wastewater methane emissions, which are currently under-reported in published industry data. For example, the most recent environmental 
353

354

355

356

357

358

359

360

361

362

363

364

performance review of the red meat processing sector (Ridoutt et al., 2015) reported a greenhouse gas emission of 0.43 t $\mathrm{CO}_{2 \text {-eq }} / \mathrm{t} \mathrm{HSCW}$, with $44 \%$ of emissions from Scope 1 (onsite) sources and $39 \%$ of Scope 1 emissions from wastewater treatment, which equates to $0.07 \mathrm{t} \mathrm{CO}_{2 \text {-eq }} / \mathrm{t} \mathrm{HSCW}$ from wastewater. This is significantly lower than the value obtained when using the default NGER value of $0.42 \mathrm{t} \mathrm{CO}$-eq $/ \mathrm{t} \mathrm{HSCW}$. The industry average figure includes an unknown number of sites that have installed covers on their anaerobic ponds, and capture and utilise the wastewater biomethane in onsite boilers, which would have a significant impact on the net greenhouse gas emissions.

Compared to the values reported in EPD studies (COOP 2016b; COOP 2016a) assuming a 3\% chiller loss, the climate change value is consistent, the fossil fuel use is significantly lower, the acidification and eutrophication potentials are significantly higher and the photochemical ozone formation potential is in the lower end of the range. This is most likely attributable to the use of coal for thermal energy at the plant, and the dominance of coal as a fuel in electricity generation in Australia. 
boundaries (LCA, current industry benchmarks and EPD), with percentage contributed by meat processing stage in parenthesis

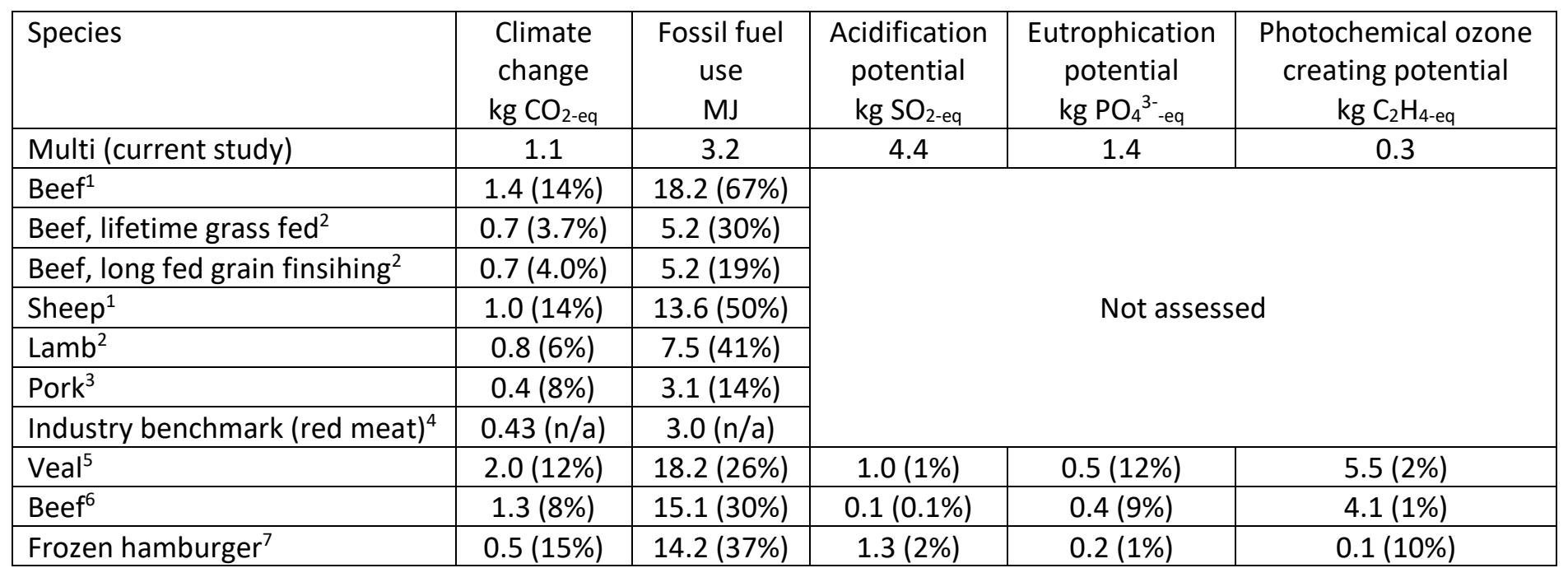

Notes: 1) - (Gregory M Peters et al., 2010), 2) - (Wiedemann et al., 2015a), long fed is 330 days in the feedlot, 3) - (Wiedemann et al., 2018), 4) - (Ridoutt et al., 2015), only covers Scope 1 and 2 emissions, 5) - (COOP, 2016b), 6) - (COOP, 2016a), 8) - (INALCA, 2018), 5-7 use energy contents of $27 \mathrm{~kJ} / \mathrm{kg}$ for coal, 42 $\mathrm{kJ} / \mathrm{kg}$ for natural gas, $35.7 \mathrm{~kJ} / \mathrm{kg}$ got oil and $39.7 \mathrm{GJ} / \mathrm{kL}$ for fuel oil with $0.9 \mathrm{~kg} / \mathrm{L}$ density. 
The full LCA results for the reference scenario are in Table 6, with separate values for before and after the inclusion of system expansion to handle the main coproducts and byproducts. Before system expansion all impact categories are emission sources. Two system expansions for replacing tallow production were analysed - palm oil (the marginal product for tallow export) and rape seed oil (the marginal product for tallow use in the domestic market).

Table 6: LCA results for reference scenario (current operation), with and without system expansion (per t HSCW)

\begin{tabular}{|c|c|c|c|c|}
\hline \multirow{2}{*}{$\begin{array}{l}\text { Mid point impact categories } \\
\text { (MIC) }\end{array}$} & \multirow[t]{2}{*}{ Unit } & \multirow{2}{*}{$\begin{array}{c}\text { Before system } \\
\text { expansion }\end{array}$} & \multicolumn{2}{|c|}{ After system expansion $^{a}$} \\
\hline & & & Palm oil & Rape seed oil \\
\hline Climate change & $\mathrm{kg} \mathrm{CO}$ 2-eq & 1,394 & $-2,236$ & $-1,996$ \\
\hline Resource depletion - mineral & $\mathrm{kg} \mathrm{Sb}-\mathrm{eq}$ & 0.000023 & -0.00010 & -0.00011 \\
\hline Resource Depletion - fossil fuels & MJ & 3,326 & $-10,400$ & $-10,900$ \\
\hline Consumptive water use & $\mathrm{m}^{3} \mathrm{H}_{2} \mathrm{O}_{\text {-eq }}$ & 847 & $-2,316$ & $-2,599$ \\
\hline Eutrophication & $\mathrm{kg} \mathrm{PO}_{4}^{3-}$-eq & 1.58 & -9.95 & -11.46 \\
\hline Acidification potential & $\mathrm{kg} \mathrm{SO}_{2 \text {-eq }}$ & 5.53 & -12.37 & -14.59 \\
\hline USEtox human & $\mathrm{CTU}_{\mathrm{h}}$ & 0.00017 & -0.00182 & -0.00183 \\
\hline USEtox eco-toxicity (freshwater) & $\mathrm{CTU}_{\mathrm{e}}$ & 3,409 & $-45,614$ & $-45,876$ \\
\hline Photochemical ozone formation & $\mathrm{kg} \mathrm{C}_{2} \mathrm{H}_{4-\mathrm{eq}}$ & 0.28 & -0.53 & -0.35 \\
\hline Particulate matter formation & kg $\mathrm{PM}_{2.5-\mathrm{eq}}$ & 0.55 & -1.68 & -1.62 \\
\hline Ozone layer depletion & kg CFC-11-eq & 0.00046 & 0.00034 & 0.00032 \\
\hline Ionizing radiation & kg U235-eq & 36.56 & -74.55 & -86.28 \\
\hline Ag Land occupation & $m^{2 * a}$ & 52 & $-2,423$ & $-2,962$ \\
\hline Endpoint impact categories (EIC) & & & & \\
\hline Ecosystems - ReCiPe (H) & species.yr & 0.000019 & -0.00032 & -0.00016 \\
\hline Human health - ReCiPe (H) & DALY & 0.0027 & -0.0046 & -0.0044 \\
\hline Resources - ReCiPe (H) & $\$$ & 56.18 & -39.31 & -44.00 \\
\hline
\end{tabular}

Notes - a) - includes boiler ash (modelled as negative input of natural aggregate), manure (market for soil conditioner), irrigation wastewater (market for irrigation), edible offal (market for cattle for slaughtering), hides (polyethylene), meal (protein feed, rape meal), and tallow (palm oil or rape seed oil)

After system expansion, every category of impacts except ozone layer depletion becomes a sink (negative emission), as the avoided products had higher environmental impacts. It should be noted that the avoided products include the entire supply chain, whereas this gate-to-gate LCA only included the core and transport sections of the supply chain, not the on-farm contributions. Edible offal, which was modelled as market for cattle for slaughtering, provided the largest credit, ranging 
from $67 \%$ for the mineral resource depletion MIC to $120 \%$ for the acidification potential MIC, and $47 \%$ for the ecosystems EIC to $121 \%$ for the human health EIC. Tallow, which was initially modelled as palm oil, was the second largest contributor in most MIC and EIC, except several categories (mineral and fossil fuel depletion, consumptive water use, acidification potential and ionizing radiation MIC, and resources EIC) where hides (modelled as polyethylene fleece) was a more significant contributor. In other studies, tallow has been modelled as canola (rape seed) oil, so this was modelled as an alternative system expansion. In the climate change, photochemical ozone formation and particulate matter formation MIC, palm oil performs better, but in every other category, rape seed oil performs better. In terms of end point impact categories, palm oil was better for ecosystems and human health (due to the contribution of climate change to these impact categories) while rape seed oil was better for the resources end point impact category. However, the difference between the two system expansions for tallow was less significant than the difference between before and after system expansion.

\subsection{Contribution analysis and circular economy opportunities - reference scenario (current operation)}

As indicated in Table 7, the most significant contributing process for climate change before system expansion was the methane emitted from the onsite wastewater treatment ponds (34\%), followed by coal use in the boiler $(20 \%)$, road transport ( $15 \%$ in total, with $6 \%$ from site fuel use) and imported electricity (7\%). This is consistent with the literature (GHD, 2011; Hydro Tasmania Consulting, 2009; Ridoutt et al., 2015; Rowlands et al., 2007; URS Australia Pty Ltd, 2005). Climate change contributes significantly to the ecosystems and human health EIC categories, so wastewater methane emissions contribute $16 \%$ and $19 \%$ respectively to these categories, but not to any other MIC. Other than the wastewater methane emissions, the climate change impact category is similar to the acidification, photochemical ozone formation and particulate matter formation MIC in terms of contributing processes. USEtox human and ecotoxicity have similar contributing processes, as do fossil fuel resource depletion and consumptive water use. Other MIC categories, such as eutrophication, mineral resource depletion, ozone layer depletion and agricultural land occupation, have quite different contributing processes: most of the eutrophication impacts come from the onsite wastewater treatment process; $34 \%$ of the mineral depletion comes from the cardboard box use; $73 \%$ of the ozone layer depletion comes from the onsite refrigeration system; and $66 \%$ of the agricultural land use comes from the cardboard box use. This indicates that climate change may not be a suitable proxy for this stage in the supply chain and further investigation is required. 
417 Coal use in the onsite boiler was the most significant process to the most categories, contributing to 418 acidification (42\%), photochemical ozone formation (32\%), particulate matter formation (28\%) and 419 EIC human health (22\%). Other significant processes which contributed to MIC and EIC categories 420 include: electricity use, to fossil fuel resource depletion (44\%) and consumptive water use (37\%); 421 cardboard box use, to mineral resource depletion (34\%) and agricultural land use (66\%); manure 422 handling, to USEtox human (33\%) and ecotoxicity (37\%); wastewater nutrients emissions, to 423 eutrophication (64\%); and the refrigeration system, to ozone layer depletion (73\%).

424 Table 7 highlights the potential benefits of the opportunities identified in Table 4, namely that 425 replacing grid purchased electricity with a renewable energy supply could potentially provide 426 improvements in line with Principle 2 (reducing fossil fuel resource depletion and consumptive water 427 use) and Principle 3 (reducing USEtox human and ecotoxicity MIC), and using the wastewater 428 methane to provide this electricity in line with Principle 2 would potentially improve the climate 429 change MIC and ecosystems and human health EIC (Principle 3). Replacing coal use in the boiler 430 with a fuel with a lower environmental burden would also provide an opportunity to reduce impacts 431 in the climate change, acidification potential, photochemical ozone formation and particulate matter 432 formation MIC, as well as the ecosystems and human health EIC. Although replacing coal use with 433 biomass in the boiler was not a high priority cost or risk issue (Principle 2), it was identified as an 434 opportunity to optimise the reuse of nutrients in the wastewater (Principle 2 and 3). 
Table 7: Percentage contribution of processes to impact categories before system expansion (values less than $1 \%$ generally not included)

\begin{tabular}{|c|c|c|c|c|c|c|c|c|c|c|c|c|c|c|}
\hline Impact category & Unit & 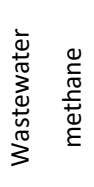 & 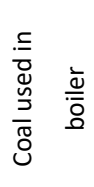 & 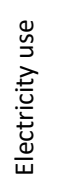 & 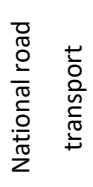 & 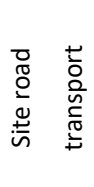 & 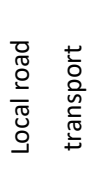 & 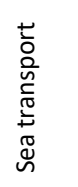 & 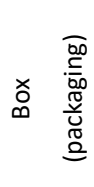 & 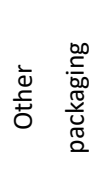 & $\begin{array}{l}\text { 营 } \\
\text { 产 }\end{array}$ & 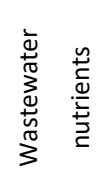 & 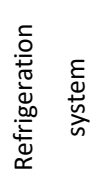 & 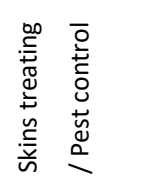 \\
\hline Climate change & $\mathrm{kg} \mathrm{CO}_{2}$ eq & $34 \%$ & $20 \%$ & $7 \%$ & $7 \%$ & $6 \%$ & $2 \%$ & $2 \%$ & $2 \%$ & $3 \%$ & $2 \%$ & & $0.4 \%$ & \\
\hline Resource depletion - mineral & kg Sb eq & & & $2 \%$ & & & & & $34 \%$ & $4 \%$ & $2 \%$ & & & \\
\hline Resource depletion - fossil fuel & MJ & & & $44 \%$ & & & & $3 \%$ & $12 \%$ & $13 \%$ & $3 \%$ & & & \\
\hline Consumptive water use & $\mathrm{m}^{3} \mathrm{H}_{2} \mathrm{O}$ eq & & & $37 \%$ & & & & $6 \%$ & $12 \%$ & $11 \%$ & $3 \%$ & & & \\
\hline Eutrophication & $\mathrm{kg} \mathrm{PO}_{4}$ & & $5 \%$ & $5 \%$ & $3 \%$ & $2 \%$ & $1 \%$ & $4 \%$ & $2 \%$ & $2 \%$ & $3 \%$ & $64 \%$ & & \\
\hline Acidification potential & $\mathrm{kg} \mathrm{SO}{ }_{2}$ eq & & $42 \%$ & $7 \%$ & $3 \%$ & $3 \%$ & $1 \%$ & $12 \%$ & $3 \%$ & $3 \%$ & $2 \%$ & & & \\
\hline USEtox human & CTUh & & & $31 \%$ & & & & $2 \%$ & $5 \%$ & $3 \%$ & $33 \%$ & & & \\
\hline USEtox ecotoxicity & CTUe & & & $29 \%$ & & & & $1 \%$ & $5 \%$ & $3 \%$ & $37 \%$ & & & $1 \% / 0.1 \%$ \\
\hline Photochemical ozone formation & $\mathrm{kg} \mathrm{C}_{2} \mathrm{H}_{4}$ eq & & $32 \%$ & $5 \%$ & $1 \%$ & $1 \%$ & & $8 \%$ & $3 \%$ & $3 \%$ & $3 \%$ & & & \\
\hline Particulate matter formation & $\mathrm{kg} \mathrm{PM} 2.5$ eq & & $28 \%$ & $5 \%$ & $1 \%$ & $1 \%$ & & $9 \%$ & $6 \%$ & $6 \%$ & $2 \%$ & & & \\
\hline Ozone layer depletion & kg CFC-11 eq & & & & & & & $1 \%$ & $1 \%$ & $8 \%$ & & & $73 \%$ & \\
\hline Ionizing radiation & kg U235 eq & & & & & & & $9 \%$ & $12 \%$ & $8 \%$ & $2 \%$ & & & \\
\hline Agricultural land occupation & $\mathrm{m}^{2 *}$ year & & & $3 \%$ & & & & $1 \%$ & $66 \%$ & $17 \%$ & $4 \%$ & & & \\
\hline Ecosystems - ReCiPe $(\mathrm{H})$ & species*year & $16 \%$ & $12 \%$ & $5 \%$ & $4 \%$ & $4 \%$ & $1 \%$ & $2 \%$ & $6 \%$ & $3 \%$ & $2 \%$ & & $0.3 \%$ & \\
\hline Human health - ReCiPe $(H)$ & DALY & $19 \%$ & $22 \%$ & $9 \%$ & $6 \%$ & $5 \%$ & $1 \%$ & $4 \%$ & $3 \%$ & $3 \%$ & $3 \%$ & & $0.3 \%$ & \\
\hline Resources - ReCiPe (H) & $\$$ & & & $8 \%$ & & & & $3 \%$ & $3 \%$ & $3 \%$ & $1 \%$ & & & \\
\hline
\end{tabular}




\subsection{Scenarios}

As indicated in Figure 3, where the best performance is indicated by the value 1, the biomass scenarios provided the best performance for eleven of the thirteen MIC categories and two of the three EIC categories, although in some categories (mineral resource depletion, USEtox human and ozone layer depletion) the performance was the same as the tallow and biogas scenarios. The remaining categories, particulate matter formation, agricultural land occupation and ecosystems damage, the values for the biomass scenario were $0.94,0.97$ and 0.79 respectively, meaning the biomass scenario had only slightly lower performance than the efficiency scenario (which had a value of 1). The reference scenario was the worst performing in $12 \mathrm{MIC}$ and $2 \mathrm{EIC}$ categories, and the tallow scenario was the worst in the photochemical ozone formation category (0.72) and equal worst with the biogas scenario (0.5) in the ecosystems EIC category. The biomass scenario performed poorly in the ecosystem EIC category due to the reduced credit from the tallow use for biodiesel and electricity production, so if tallow use in electricity production could be reduced, for example by the use of a larger solar photovoltaic system, then this ranking could be improved. However, care should be taken in interpreting the results.

Figure 3: Comparison of scenarios ( 1 = best performance), with palm oil as the system expansion for tallow (REF is reference scenario, EFF is efficiency scenario, TAL is tallow scenario, BGS is biogas scenario and BM is biomass scenario, as outlined in Table 1)

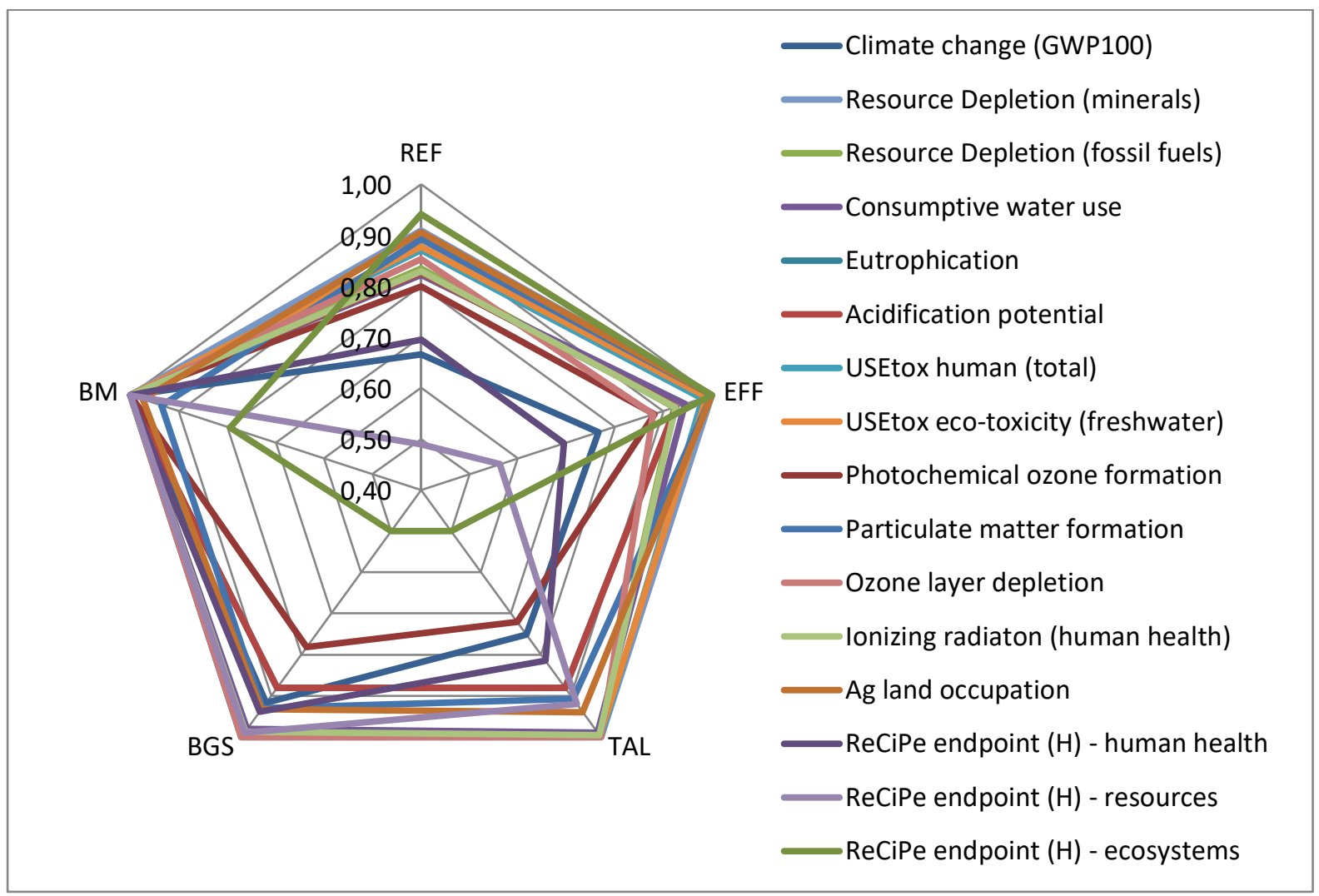


456

457

458

459

460

461

462

463

464

465

466

467

468

469

470

As Indicated in Figure 4, the avoided products make a significant percentage contribution to the climate change impact category, and are the reason that the category becomes a sink. Edible offal, the main coproduct, is the most significant sink contributor in all MIC and EIC in all scenarios, and although the absolute amount remains unchanged, the relative contribution changes in each scenario. The same holds for meal and hides, but those byproducts have a smaller contribution to the sink. The contribution of tallow varies according to how much is used in each scenario.

Figure 4: Percentage contribution of system expansion to climate change category impacts

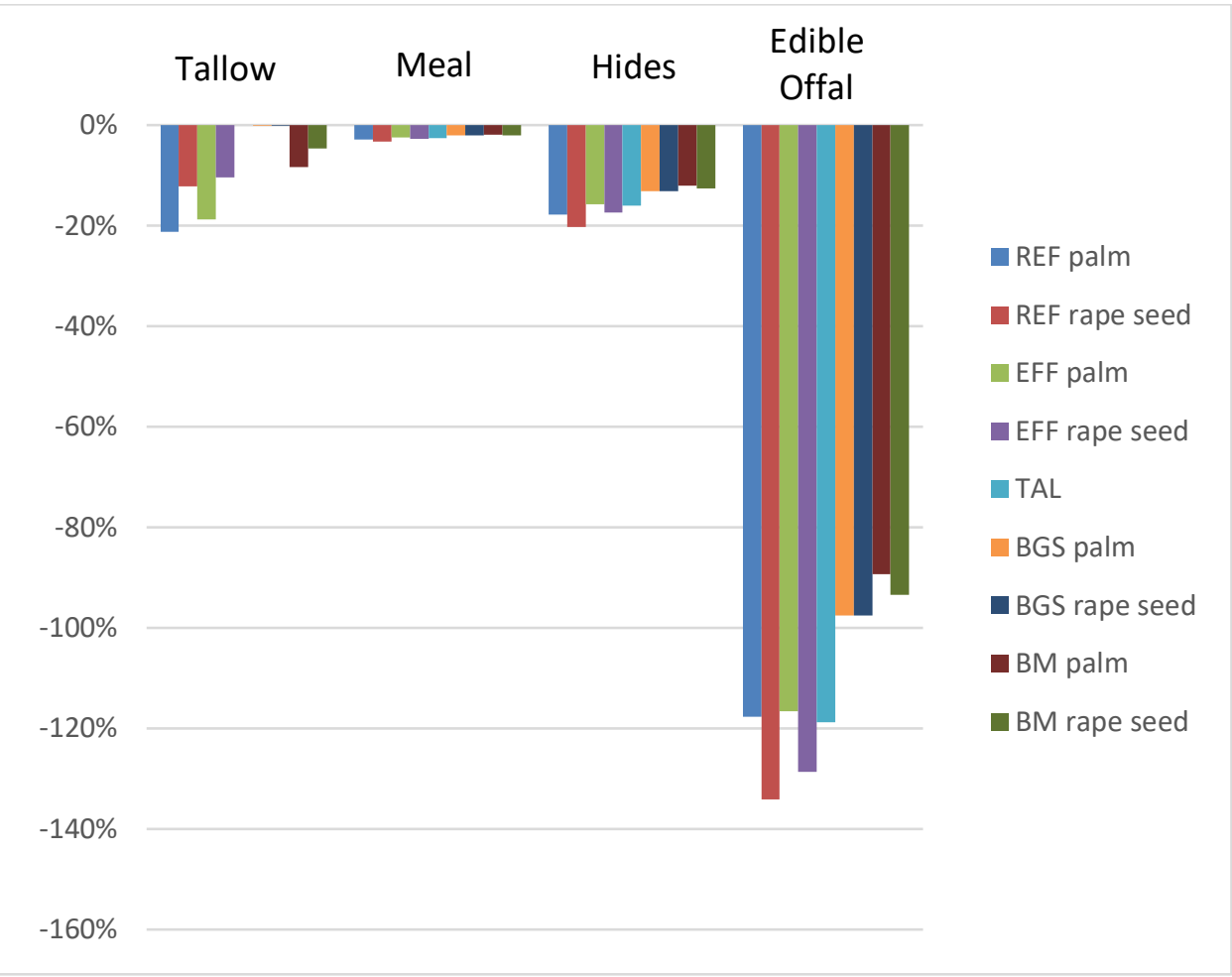

The sources of greenhouse gas emissions are shown in Figure 5 for individual processes, with the main system expansion credits from edible offal, hides and meal removed. This is consistent with the numbers in Table 7, and shows the trade-off in the TAL, BGS and BMS cases between reducing emissions from the boiler and the reduction in credit from the tallow system expansion, which accounts for why the BM scenario is the best performing.

Figure 5: Contribution to climate change impact category when main sinks from coproduct byproduct system expansion are removed. 


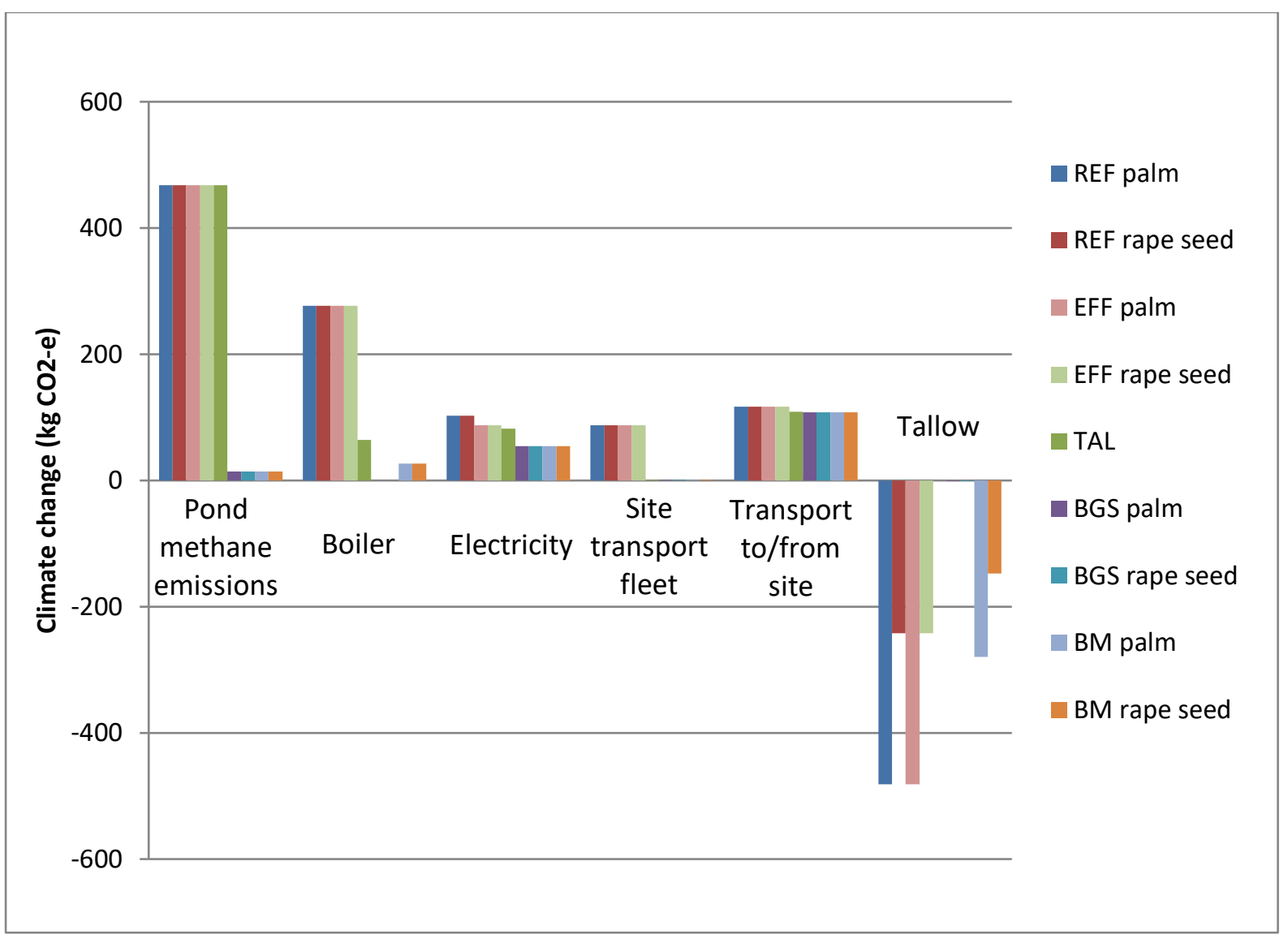

473 The biomass potential production rate of $83 \mathrm{GJ} / \mathrm{ha} / \mathrm{year}$ was compared to the amount of energy

474 required for the plant (thermal and total), and results indicated that 0.03 ha of land was required per

$475 \mathrm{t} \mathrm{HSCW}$ to provide the thermal energy needs $(2,739 \mathrm{MJ} / \mathrm{t} \mathrm{HSCW})$. This was then compared to the

476 hectares of land required to produce each t HSCW of livestock, and the results are presented in

477 Table 8 and indicate that in all cases less than $0.5 \%$ of the livestock catchment area is required to

478 provide the thermal requirements and only beef finished in feedlots for more than 300 days (long

479 fed beef) require more than 1\% of the catchment area. Lifetime grass fed beef requires the smallest

480 amount of the catchment area, and lamb and mid fed beef (grain fed for 108-164 days) are slightly

481 higher but long fed beef require double the amount. If we assume a worst case supply chain

482 emission of greenhouse gases per t HSCW (25.5 kg CO $2-e$, (Gregory M. Peters et al., 2010)) and look

483 at offsetting greenhouse gas emissions by replacing an equivalent greenhouse gas emissions amount

484 of coal with biomass grown on the farm, then lifetime grass fed beef has the best performance, with

$48512 \%$ of the livestock capture area required for offsets, as opposed to long fed beef, which requires

$48630 \%$. This assessment is conservative, as it does not include any increase in soil carbon due to a

487 change from pasture to biomass production. Given the regional location and surrounding land use at

488 the SME study site, it should be technically feasible within a $150 \mathrm{~km}$ radius of the plant. 
Table 8: Percentage of livestock capture area of plant compared to area required for energy and greenhouse needs (land use data derived from (Wiedemann et al., 2015b)

\begin{tabular}{|l|c|c|c|c|}
\hline \multicolumn{1}{|c|}{ ha/t HSCW } & $\begin{array}{c}\text { Beef (lifetime } \\
\text { grass fed) }\end{array}$ & $\begin{array}{c}\text { Beef (mid fed } \\
\text { grain finished) }\end{array}$ & $\begin{array}{c}\text { Beef (long fed } \\
\text { grain finished) }\end{array}$ & Lamb \\
\hline Non-arable & 29.3 & 21.8 & 11.6 & 21.4 \\
\hline Arable pasture & 1.5 & 1.1 & 0.6 & 1.1 \\
\hline Arable crop & 0.2 & 1.2 & 2.1 & 0.2 \\
\hline Total & 31 & 24.1 & 14.3 & 22.7 \\
\hline \% required, thermal energy & $0.1 \%$ & $0.2 \%$ & $0.3 \%$ & $0.2 \%$ \\
\hline \% required, offset + thermal energy & $11.8 \%$ & $15.8 \%$ & $29.8 \%$ & $16.1 \%$ \\
\hline
\end{tabular}

491

\section{Conclusions and recommendations}

\subsection{Risk and LCA}

The use of risk and cost screenings at the life cycle inventory stage to prioritise issues for the site provided a useful introduction to the gate-to-gate LCA. This assisted with identifying the circular economy opportunities with upstream and downstream, which were then investigated as part of the LCA study. Serendipitously, the risk and cost screenings aligned well with each other, and with the impacts identified in the reference case of the current operation.

\subsection{Gate to gate LCA of current operation}

The analysis indicated that current life cycle inventories and LCA results for MIC climate change and fossil fuel are significantly different to this analysis, so it would appear that SMEs, such as the plant in this study, may not be well represented by current life cycle inventories or LCA studies. There are a number of categories that have not previously been assessed in LCA studies, but given the difference in inventory data, it is likely that the results for other MIC would also be significantly different. Similarly, the current reported levels of wastewater methane emissions in industry benchmarking reports does not appear to reflect current SME operations, which are less likely to have biogas capture and use.

Analysing the results before and after the allocation of the system expansion credits highlighted the contribution of coproducts and byproducts, with edible offal contributing the most significant credit, ranging from $56 \%$ for ecosystems EIC to $120 \%$ for climate change and acidification MIC. Changing the usage rates of this byproduct is not something an individual SME could necessarily influence, but it would need to be handled on an industry basis.

The individual process contribution highlighted that climate change was different to other MIC but similar to ecosystems and human health EIC, so was possibly not suitable as a representative MIC. Wastewater emissions and boiler coal use were most significant in terms of these three categories. 
516

517

518

519

520

521

522

523

524

525

526

527

528

529

530

531

532

533

534

535

536

537

538

539

540

541

542

543

544

545

Eutrophication, acidification potential, photochemical ozone formation and particulate matter formation had similar individual process contributions, as did fossil fuel resource depletion, consumptive water use, USEtox human and ecotoxicity and the resources end point indicator.

\subsection{Future scenarios, offsets and sequestration.}

The best future energy supply option was the biomass scenario, which captured and used wastewater methane from the onsite wastewater treatment system for onsite power generation, used tallow produced at the plant for biodiesel production for the site transport fleet and residual electricity production and then sourced all thermal energy requirements from biomass production.

The amount of land required to produce biomass to replace the current thermal energy requirements was small $(0.03$ hectares or $<0.5 \%$ of non-arable land required to produce red meat livestock). If the worst case emission for beef ( $25.5 \mathrm{~kg} \mathrm{CO}_{2-\mathrm{e}} / \mathrm{kg} \mathrm{HSCW}$ ) were offset using biomass to replace coal in addition to replacing all energy use at the plant, the land area required would be 3.6 hectares, which ranged from $12 \%$ of non-arable land in the case of lifetime grass fed beef to $31 \%$ of non-arable land for long fed grain finished beef. The latter value is not likely to be feasible for economic reasons, but a $12 \%$ increase in the amount of biomass on a property while maintaining productivity is possibly feasible, meaning that grass fed beef systems may have the most potential for whole of supply chain greenhouse gas offsets through biomass production on non-arable land and subsequent use for fossil fuel offsets. This assessment is conservative, in that it does not include any sequestration from increases in soil carbon in the analysis.

\subsection{Circular economy}

This study highlighted the potential for supply chain integration for both energy and nutrients in red meat supply chains. LCA provides a useful means of assessing all the categories of impacts, rather than single categories such as climate change, water or land use, as has been the case with previous LCAs. This study indicates that there is potential for processing plants, which represent the core of the supply chain, to exploit circular economy opportunities, particularly with the upstream on-farm production part of the supply chain.

\subsection{Limitations and future work}

This study was based on a single SME plant, so further work should be done to confirm whether or not other SME plants have similar issues with life cycle inventory data. Risks and opportunities will vary between sites, as will energy costs and availability. The potential for wastewater recycling and 
546

biomass production should be investigated further to assess the feasibility and supply chain offset potential.

\section{Acknowledgements}

The study was undertaken as part of a self funded PhD project at DTU. The first author would like to thanks the management at Eversons Food Processing for the provision of the primary data used in this study.

\section{References}

Anderson, A.D., Smoak, B., Shuping, E., Ockenhouse, C., Petruccelli, B., 2005. Q fever and the US military. Emerg. Infect. Dis. 11, 1320-2. https://doi.org/10.3201/eid1108.050314

Australian Bureau of Statistics, 2018. 7503 - Value of Agricultural Commodities Produced, Australia, 2016-2017 [WWW Document]. URL http://www.abs.gov.au/ausstats/abs@.nsf/mf/7503.0

Australian Bureau of Statistics, 2017. Land Use, Australia, year ended 30 June 2016 [WWW Document]. 7120.0 - Agric. Commod. Aust. 2015-2016. URL http://www.abs.gov.au/ausstats/abs@.nsf/Latestproducts/7121.0Main Features31201516 ?opendocument \&tabname=Summary \&prodno=7121.0\&issue $=2015-16 \&$ num $=\& v i e w=$

Australian Bureau of Statistics, 2015. 9208.0 - Survey of Motor Vehicle Use, Australia, 12 months ended 31 October 2014. Canberra.

Australian Government Clean Energy Regulator, 2018. NGER Wastewater Industrial Calculator 20162017 [WWW Document]. XLXS Doc. URL http://www.cleanenergyregulator.gov.au/DocumentAssets/Pages/NGER-WastewaterIndustrial-Calculator-2016-2017.aspx (accessed 4.23.19).

Australian Government Department of Agriculture and Water Resources, 2018. Australia's Farming Future - Adapting to a changing climate [WWW Document]. Clim. Chang. Res. Progr. URL http://www.agriculture.gov.au/ag-farm-food/climatechange/australias-farmingfuture/adapting-to-a-changing-climate

Cederberg, C., Berglund, M., Gustavsson, J., Wallman, M., 2012. Environmental impacts from livestock production with different animal welfare potentials - a literature review.

Center For Disease Control, 2012. Q Fever [WWW Document]. 2012 West Nile virus Updat. URL http://www.cdc.gov/ncidod/dvbid/westnile/index.htm 
Clean Energy Council, 2017. Guide to installing solar PV for households in New South Wales. Sydney.

COOP, 2016a. Environmental Product Declaration of Coop Beef Meat.

COOP, 2016b. Environmental Product declaration of Coop Veal Meat. COOP.

Coopers and Lybrand Consultants, 1996. Trends and future regulatory issues concerning packaging material used in the Australian meat industry (Technical Report M.713). North Sydney.

CSIRO, 2002. Tallow as a heating fuel. CSIRO Meat Updat. September, 3.

CSIRO and Bureau of Meteorology, 2015. Climate Change in Australia - Information for Australia's Natural Resource Management Regions: Technical Report. Australia.

Dahlgren, F.S., Haberling, D.L., McQuiston, J.H., 2015a. Q fever is underestimated in the United states: A comparison of fatal $Q$ fever cases from two national reporting systems. Am. J. Trop. Med. Hyg. 92, 244-246. https://doi.org/10.4269/ajtmh.14-0502

Dahlgren, F.S., McQuiston, J.H., Massung, R.F., Anderson, A.D., 2015b. Q fever in the United States: Summary of case reports from two national surveillance systems, 2000-2012. Am. J. Trop. Med. Hyg. 92, 247-255. https://doi.org/10.4269/ajtmh.14-0503

Dames \& Moore Pty Ltd, 1999. Generic manual for development of environmental management systems at meat processing plants in Australia (RPDA.302). Sydney.

Department of Agriculture and Water Resources, 2017. Mid North Coast NSW Regional Profile [WWW Document]. ABARES. URL http://www.agriculture.gov.au/abares/researchtopics/aboutmyregion/mid-north-coast\#agricultural-sector

Department of the Environment and Energy, 2016a. National Greenhouse Accounts Factors, Australian National Greenhouse Accounts. Canberra, ACT.

Department of the Environment and Energy, 2016b. National Greenhouse and Energy Reporting Scheme, Technical Guidelines for the estimation of emissions by facilities in Australia, 20152016 reporting year. Canberra. https://doi.org/http://www.environment.gov.au

Dufour, J., Iribarren, D., 2012. Life cycle assessment of biodiesel production from free fatty acid-rich wastes. Renew. Energy 38, 155-162. https://doi.org/10.1016/j.renene.2011.07.016

Dufty, N., 2010. Leading practice in the environmental management of New South Wales linear reserves - the role of the NSW Roadside Environment Committee. Australas. Plant Conserv. 19. 
603

604

605

606

607

608

609

610

611

612

613

614

615

616

618

619

620

621

622

623

Eastwood, K., Massey, P.D., Hutchinson, P., van den Berg, D., Bosward, K., Graves, S.R., 2018. Q fever: A rural disease with potential urban consequences. Aust. J. Gen. Pract. 47, 5555.

EC-JRC, 2010. (ILCD) Handbook: General guide for Life Cycle Assessment - Detailed guidance. Luxembourg. https://doi.org/10.2788/38479

Ellen MacArthur Foundation, 2015. Circular Economy Overview [WWW Document]. URL https://www.ellenmacarthurfoundation.org/circular-economy (accessed 6.17.17).

Ellen MacArthur Foundation, McKinsey Centre for Business and Environment, Stiftungsfonds für Umweltökonomie und Nachhaltigkeit (SUN), 2015. GROWTH WITHIN: A CIRCULAR ECONOMY VISION FOR A COMPETITIVE EUROPE.

Emerson Climate Technologies, 2010a. Refrigerant Choices for Commercial Refrigeration. Aachen, Germany.

Emerson Climate Technologies, 2010b. Refrigerant Choices for Commercial Refrigeration - Finding the Right Balance. Aachen, Germany.

FAO, 2012. Energy-Smart Food at FAO: An Overivew. Rome.

GE Power, 2016. Jenbacher type 2 fact sheet.

GHD, 2011. Industry environmental sustainability review 2010 (A.ENV.0086). North Sydney.

Gidding, H.F., Wallace, C., Lawrence, G.L., McIntyre, P.B., 2009. Australia's national Q fever vaccination program. Vaccine 27, 2037-2041. https://doi.org/10.1016/j.vaccine.2009.02.007

Harris-Adams, K., Townsend, P., Lawson, K., 2012. Native vegetation management on agricultural land, ABARES Research Report 12.10. Canberra.

Heathcote, R., 2002. Case Study on Long Rotation Eucalypt Plantations in New South Wales. Rome.

Hessle, A., Bertilsson, J., Stenberg, B., Kumm, K.-I., Sonesson, U., 2017. Combining environmentally and economically sustainable dairy and beef production in Sweden. Agric. Syst. 156, 105-114. https://doi.org/10.1016/j.agsy.2017.06.004

Hydro Tasmania Consulting, 2009. Red Meat Processing Industry Energy Efficiency Manual (A.ENV.0065). North Sydney.

Inalca, 2018. Montana Canned Beef Meat EPD. 
630

631

632

633

634

635

636

637

638

639

640

641

642

INALCA, 2018. Frozen Hamburger (in Italian).

Jensen, P., Batstone, D., 2012. Energy and Nutrient analysis on Individual Waste Streams (Final Report Project A.ENV.0131).

Leahy, E., Lyons, S., Tol, R.S.J., 2010. An Estimate of the Number of Vegetarians in the World. ESRI Work. Pap. 340 1-44. https://doi.org/10.1007/s10273-011-1262-2

Lowbridge, C.P., Tobin, S., Seale, H., Ferson, M.J., 2012. Notifications of Q fever in NSW, 2001-2010. NSW Public Heal. Bull. 23, 31-35. https://doi.org/10.1071/NB11037

Mayberry, D., Bartlett, H., Moss, J., Wiedemann, S., Herrero, M., 2018. Greenhouse Gas mitigation potential of the Australian red meat production and processing sectors - Executive Summary. North Sydney.

Meat \& Livestock Australia, 2018. Statistics Database [WWW Document]. Mark. Inf. URL http://statistics.mla.com.au/Report/List

Meat \& Livestock Australia, 2017. Sheep numbers - as at June 2017, Natural Resource Management Region [WWW Document]. URL https://www.mla.com.au/globalassets/mla-corporate/prices-markets/documents/trends--analysis/fast-facts--maps/sheep-numbers-map-2018-as-at-june2017-data.pdf (accessed 2.26.19).

Mpelasoka, F., Hennessy, K., Jones, R., Bates, B., 2008. Comparison of suitable drought indices for climate change impacts assessment over Australia towards resource managmenet. Int. J. Climatol. 28, 1283-1292. https://doi.org/10.1002/joc.1649

Nardone, A., Ronchi, B., Lacetera, N., Ranieri, M.S., Bernabucci, U., 2010. Effects of climate changes on animal production and sustainability of livestock systems. Livest. Sci. 130, 57-69. https://doi.org/10.1016/j.livsci.2010.02.011

Notarnicola, B., Sala, S., Anton, A., McLaren, S.J., Saouter, E., Sonesson, U., 2017. The role of life cycle assessment in supporting sustainable agri-food systems: A review of the challenges. J. Clean. Prod. 140, 399-409. https://doi.org/10.1016/j.jclepro.2016.06.071

Nourse, C., Allworth, A., Jones, A., Horvath, R., McCormack, J., Bartlett, J., Hayes, D., Robson, J.M., 2004. Three cases of $Q$ fever osteomyelitis in children and a review of the literature. Clin Infect Dis 39, e61-6. https://doi.org/10.1086/424014

NSW Environment Protection Authority, 2015. Licence summary - site 3117 [WWW Document]. URL 
659

660

661

662

663

664

665

666

667

668

669

670

671

672

673

674

675

676

677

678

679

680

681

682

https://apps.epa.nsw.gov.au/prpoeoapp/Detail.aspx?instid=3117\&id=3117\&option=licence\&se archrange=licence $\&$ range=POEO licence $\& p r p=$ no $\&$ status=Issued

NSW Environment Protection Authority, 2010. Strategic environmental compliance and performance review: Effluent Reuse Management. Sydney.

NSW Environment Protection Authority, 2009. Strategic Environmental Compliance and Performance Review - Industry Monitoring. Sydney.

NSW Environment Protection Authority, 2003. Industry Sector: Livestock Processing Industries (Animal Slaughter and Rendering), Compliance Performance Report. Sydney.

O'CONNOR, B.A., TRIBE, I.G., GIVNEY, R., 2015. A windy day in a sheep saleyard: an outbreak of Q fever in rural South Australia. Epidemiol. Infect. 143, 391-398.

https://doi.org/10.1017/S0950268814001083

OECD, 2005. Small and medium-sized enterprises (SMEs) Definition [WWW Document]. OECD Gloss. Stat. Terms . URL https://stats.oecd.org/glossary/detail.asp?ID=3123 (accessed 3.19.19).

Office of Environment \& Heritage, 2011. Guide to Climate Change Risk Assessment for NSW Local Government. Sydney.

Pagan, R., Renouf, M., Prasad, P., 2002. Eco-Efficiency Manual for Meat Processing. Meat \& Livestock Australia, North Sydney.

Paolotti, L., Boggia, A., Castellini, C., Rocchi, L., Rosati, A., 2016. Combining livestock and tree crops to improve sustainability in agriculture: a case study using the Life Cycle Assessment (LCA) approach. J. Clean. Prod. 131, 351-363. https://doi.org/10.1016/j.jclepro.2016.05.024

Peters, G.M., Rowley, H., Tucker, R., Wiedemann, S.G., Short, M., Schulz, M., Feitz, A., 2009. Southern Red Meat Production - a Life Cycle Assessment, Final Report Project COMP.094. North Sydney. https://doi.org/10.1007/s11367-010-0161-x

Peters, Gregory M., Rowley, H. V., Wiedemann, S.G., Tucker, R., Short, M.D., Schulz, M., 2010. Red Meat Production in Australia: Life Cycle Assessment and Comparison with Overseas Studies. Environ. Sci. Technol. 44, 1327-1332. https://doi.org/10.1021/es901131e

Peters, Gregory M, Rowley, H. V, Wiedemann, S.G., Tucker, R., Short, M.D., Schulz, M., 2010. Red Meat Production in Australia: Life Cycle Assessment and Comparison with Overseas Studies (Supporting information). Environ. Sci. Technol. 44, 6. 

https://doi.org/https://pubs.acs.org/doi/suppl/10.1021/es901131e/suppl_file/es901131e_si_0 01.pdf

Poeschl, M., Ward, S., Owende, P., 2012. Environmental impacts of biogas deployment - Part I: life cycle inventory for evaluation of production process emissions to air. J. Clean. Prod. 24, 168183. https://doi.org/10.1016/j.jclepro.2011.10.039

Renouf, M.A., Grant, T., Sevenster, M., Logie, J., Ridoutt, B., Ximenes, F., Bengtsson, J., Cowie, A., Lane, J., 2016. Best Practice Guide for Life Cycle Impact Assessment in Australia.

Reyenga, P.J., Howden, S.M., Meinke, H., Hall, W.B., n.d. Global change impacts on wheat production along an environmental gradient in south Australia.

Ridoutt, B., Sanguansri, P., Alexander, D., 2015. Environmental Performance Review : Red Meat Processing Sector 2015. North Sydney.

Rockström, J., Steffen, W., Noone, K., Persson, Å., Chapin, F.S., Lambin, E., Lenton, T.M., Scheffer, M., Folke, C., Schellnhuber, H.J., Nykvist, B., de Wit, C.A., Hughes, T., van der Leeuw, S., Rodhe, H., Sörlin, S., Snyder, P.K., Costanza, R., Svedin, U., Falkenmark, M., Karlberg, L., Corell, R.W., Fabry, V.J., Hansen, J., Walker, B., Liverman, D., Richardson, K., Crutzen, P., Foley, J., 2009. Planetary boundaries: Exploring the safe operating space for humanity. Ecol. Soc. 461, 4. https://doi.org/10.5751/ES-03180-140232

Rowlands, A. (Alliance C., Marlow, J. (ProAnd A., Colley, T. (Colley C.P.L., Georgius, N. (GHD P.L., Foley, J. (GHD P.L., Hertle, C. (GHD P.L., McPhail, N. (Food S.A., Porter, J. (John R.P.P.L., Schulz, T. (The O.U., Perrens, S. (Evans P.P.L., Christiansen, F. (Evans P.P.L., Sentance, C. (Food S.S., 2007. Environmental Best Practice Guidelines for the Red Meat Processing Industry, 2006th ed. Meat \& Livestock Australia, Sydney.

SAI Global, 1999. Australian/ New Zealand Standard AS/NZS 4360:1999 - Risk Management. AS/NZS 4360:1999.

Shishido, A.A., Letizia, A.G., Hartzell, J.D., 2016. Q fever. United States Army Med. Dep. J. Jan-March, 68-71. https://doi.org/10.1016/S0140-6736(06)68266-4

Sivabalan, P., Saboo, A., Yew, J., Norton, R., 2017. Q fever in an endemic region of North Queensland, Australia: A 10 year review. One Heal. 3, 51-55. https://doi.org/10.1016/j.onehlt.2017.03.002

Sloan-Gardner, T.S., MASSEY, P.D., HUTCHINSON, P., Knope, K., FEARNLEY, E., 2017. Trends and risk 
factors for human Q fever in Australia, 1991-2014. Epidemiol. Infect. 145, 787-795. https://doi.org/10.1017/S0950268816002843

Sonesson, U.G., Lorentzon, K., Andersson, A., Barr, U.-K., Bertilsson, J., Borch, E., Brunius, C., Emanuelsson, M., Göransson, L., Gunnarsson, S., Hamberg, L., Hessle, A., Kumm, K.-I., Lundh, Å., Nielsen, T., Östergren, K., Salomon, E., Sindhöj, E., Stenberg, B., Stenberg, M., Sundberg, M., Wall, H., Nemecek, T.J., 2016. Paths to a sustainable food sector: integrated design and LCA of future food supply chains: the case of pork production in Sweden. Int. J. Life Cycle Assess. 21, 664-676. https://doi.org/10.1007/s11367-015-0969-5

Stahel, W.R., 2016. Circular economy. Nature 531, 435-438.

Steinfeld, H., Gerber, P., Wassenaar, T., Castel, V., Rosales, M., De Haan, C., 2006. Livestock's long shadow - environmental issues and options, Food and Agriculture Organization of the United Nations. Rome. https://doi.org/10.1007/s10666-008-9149-3

Stokes, C.J., Howden, S.., Gifford, R.., Meinke, H., Bange, M., McRae, D., Roth, G., Gaydon, D., Beecher, H.G., Reinke, R., Crimp, S., Park, S., Inman-Bamber, G., Webb, L., Barlow, E.W.R., Hennessy, K., Whetton, P.H., Booth, T.H., Kirschbaum, M.U.F., Battaglia, M., Stone, G., Cobon, D., Ash, A., McKeon, G., Miller, C.J., Jones, R.N., Hobday, A. J., A., Poloczanska, E.S., Hobday, A., Poloczanska, E.S., 2008. An overview of climate change adaptation in Australian primary industries - impacts, options and priorities.

Thomas, D.S., Henson, M., Joe, B., Boyton, S., Dickson, R., 2009. Review of growth and wood quality of plantation-grown Eucalyptus dunnii Maiden. Aust. For. 72, 3-11.

Tissot-Dupont, H., Amadei, M.A., Nezri, M., Raoult, D., 2004. Wind in November, Q fever in December. Emerg. Infect. Dis. 10, 1264-1269. https://doi.org/10.3201/eid1007.030724

Tozer, S.J., Lambert, S.B., Sloots, T.P., Nissen, M.D., 2011. Q fever seroprevalence in metropolitan samples is similar to rural/remote samples in Queensland, Australia. Eur J Clin Microbiol Infect Dis 30, 1287-1293. https://doi.org/10.1007/s10096-011-1225-y

United Nations, 2015. World Population Prospects: The 2015 Revision, Key Findings and Advance Tables, Department of Economic and Social Affairs, Population Division. https://doi.org/10.1017/СВ09781107415324.004

URS Australia Pty Ltd, 2006. Environmental Management System - Integrated Red Meat Supply Chain, Final Report A.SCC.0021. 
URS Australia Pty Ltd, 2005. Industry environmental performance review - Integrated meat processing plants (PRENV.033). North Sydney.

Whitney, E.A.S., Massung, R.F., Candee, A.J., Ailes, E.C., Myers, L.M., Patterson, N.E., Berkelman, R.L., 2009. Seroepidemiologic and Occupational Risk Survey for Coxiella burnetii Antibodies among US Veterinarians. Clin. Infect. Dis. 48, 550-557. https://doi.org/10.1086/596705

Wiedemann, S.G., 2018. Analysis of Resource Use and Greenhouse Gas Emissions from Four Australian Meat production systems, with investigation of mitigation opportunities and tradeoffs. Charles Sturt.

Wiedemann, S.G., McGahan, E., Murphy, C., Yan, M.-J., Henry, B., Thoma, G., Ledgard, S., 2015a. Environmental impacts and resource use of Australian beef and lamb exported to the USA determined using life cycle assessment - Appendix A. Supplementary data. J. Clean. Prod. 94, $67-75$.

Wiedemann, S.G., McGahan, E., Murphy, C., Yan, M.-J., Henry, B., Thoma, G., Ledgard, S., 2015b. Environmental impacts and resource use of Australian beef and lamb exported to the USA determined using life cycle assessment. J. Clean. Prod. 94, 67-75. https://doi.org/10.1016/j.jclepro.2015.01.073

Wiedemann, S.G., McGahan, E., Murphy, C., Yan, M., 2016. Resource use and environmental impacts from beef production in eastern Australia investigated using life cycle assessment. Anim. Prod. Sci. 56, 882-894. https://doi.org/10.1071/AN14687

Wiedemann, S.G., McGahan, E.J., Murphy, C.M., 2018. Environmental impacts and resource use from Australian pork production determined using life cycle assessment. 2. Energy, water and land occupation. Anim. Prod. Sci. 58, 1153. https://doi.org/10.1071/AN16196

Wiedemann, S.G., Murphy, C.M., McGahan, E.J., Bonner, S.L., Davis, R.J., 2014. Life Cycle Assessment of four southern beef supply chains - MLA Final Report Project B.FLT.0364. North Sydney.

Yanagida, T., Maita, H., Fujimoto, S., Minowa, T., 2011. LIFE CYCLE ANALYSIS OF EUCALYPTUS WOOD CHIP PRODUCTION BY SHORT ROTATION COPPICE, in: 19th European Biomass Conference and Exhibition, Berlin, Germany. pp. 6-10. https://doi.org/10.2478/s11756-009-0109-4.6 


\section{Supplementary Material 1.1}

1.1 Summary of LCA's of meat supply chains which include meat processing.

Table 9: Australian Life Cycle Assessment studies for the beef, sheep or pig supply chains that include meat processing.

\begin{tabular}{|c|c|c|c|c|}
\hline Authors & Year & Sector & Details & Results \\
\hline $\begin{array}{l}\text { Gregory M. } \\
\text { Peters, Hazel V. } \\
\text { Rowley, Stephen } \\
\text { Wiedemann, } \\
\text { Robyn Tucker, } \\
\text { Michael D. Short } \\
\text { and Matthias } \\
\text { Schulz, } \\
\text { Environmental } \\
\text { Science } \\
\text { Technology } \\
\text { Journal, 2010, 44, } \\
\text { pp 1327-1332 } \\
\text { (funded through } \\
\text { MLA Project } \\
\text { COMP.094) }\end{array}$ & 2010 & $\begin{array}{l}\text { Sheep (WA), } \\
\text { Beef (organic } \\
\text { grass fed } \\
\text { (VIC)) } \\
\text { Beef (grain lot } \\
\text { fed) (NSW) }\end{array}$ & $\begin{array}{l}\text {-Attributional LCA } \\
\text {-3 case study farms and } 1 \text { feedlot over } 2 \\
\text { years ( } 2002 \text { and } 2004 \text { ) } \\
\text { - System boundary from farm to meat } \\
\text { processing plant boundary } \\
\text { - Functional unit - } 1 \mathrm{~kg} \text { HSCW at exit gate } \\
\text { of meat processing plant } \\
\text { - Excludes CO2-e emissions from soil } \\
\text { carbon, land use, direct land use change } \\
\text { and nitrous oxide emissions from } \\
\text { leguminous pastures } \\
\text {-Allocation of impacts to coproducts } \\
\text { based on mass } \\
\text { - Meat processing inventory per t HSCW - } \\
400 \text { kWh electricity, } 53 \text { kg coal, } 0.8 \mathrm{~m}^{3} \\
\text { LPG, } 7 \text { kL water consumption }\end{array}$ & 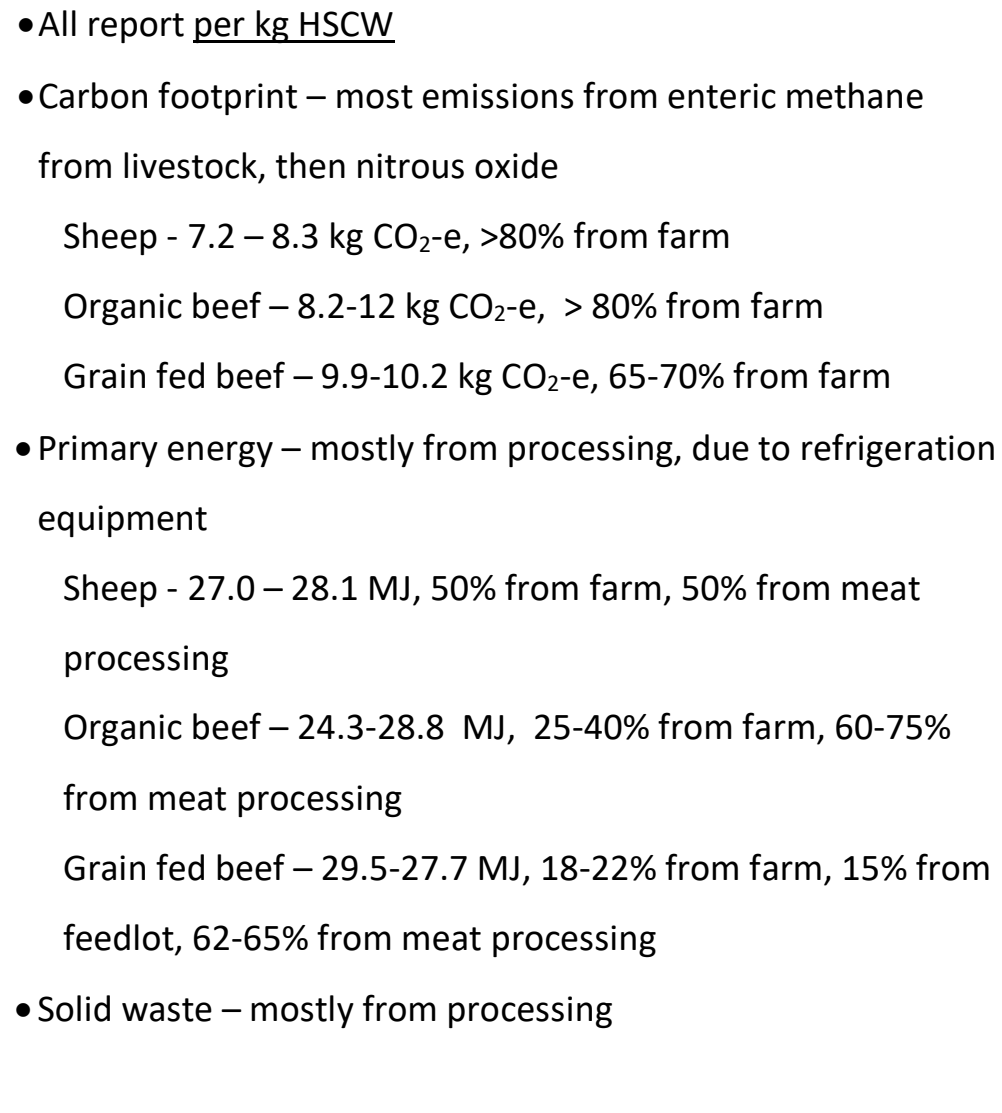 \\
\hline
\end{tabular}




\begin{tabular}{|c|c|c|c|c|}
\hline Authors & Year & Sector & Details & Results \\
\hline & & & & $\begin{array}{l}\text { Sheep }-0.021-0.022 \mathrm{~kg},>10 \% \text { from farm, remainder from } \\
\text { meat processing } \\
\text { Organic beef }-0.033-0.039 \mathrm{~kg} \text {, remainder from meat } \\
\text { processing } \\
\text { Grain fed beef }-0.028-0.029 \mathrm{~kg}, 7 \% \text { from feedlot, } \\
\text { remainder from meat processing }\end{array}$ \\
\hline $\begin{array}{l}\text { SG Wiedemann, } \\
\text { CM Murphy, EJ } \\
\text { McGahan, M } \\
\text { Renouf, P Prasad, } \\
\text { SL Bonner, EN } \\
\text { Zadow, B Henry. } \\
\text { Meat \& Livestock } \\
\text { Australia Project } \\
\text { B.CCH.2028 Final } \\
\text { Report }\end{array}$ & 2013 & $\begin{array}{l}\text { Beef } \\
\text { (Northern } \\
\text { Beef Supply } \\
\text { Chain), grass } \\
\text { fed bullocks } \\
\text { for Japan ox } \\
\text { market (NE } \\
\text { Qld), grain } \\
\text { finished beef } \\
\text { for domestic } \\
\text { market (SW } \\
\text { Qld) }\end{array}$ & $\begin{array}{l}\text { - Attributional LCA } \\
\text { - } 2 \text { case study farms, } 1 \text { feedlot and } 2 \\
\text { meat processing plants over } 24^{+} \text {months } \\
\text { - System boundary from farm to } \\
\text { consumer (paddock to plate) } \\
\text {-3 Functional units - kg LW, kg boned } \\
\text { beef ready for wholesale/retail at the } \\
\text { processor gate, kg beef at consumer in } \\
\text { Australia or Japan } \\
\text { - CO }{ }_{2-\mathrm{e}} \text { emissions excludes land use, direct } \\
\text { land use change but include soil carbon } \\
\text { flux potential } \\
\text { - System expansion to handle minor } \\
\text { byproducts (pet food, blood, meat and } \\
\text { bone meal (soymeal and sorghum on }\end{array}$ & 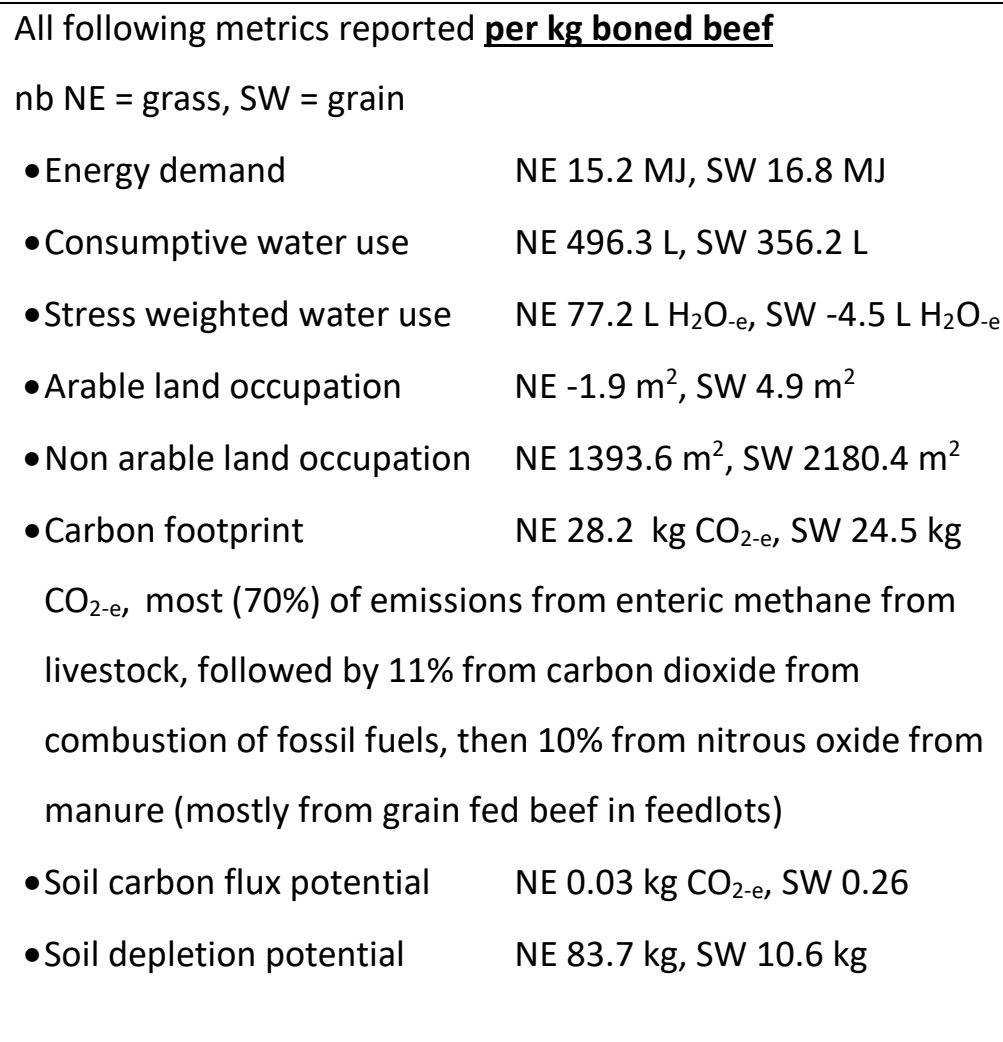 \\
\hline
\end{tabular}




\begin{tabular}{|c|c|c|c|c|}
\hline Authors & Year & Sector & Details & Results \\
\hline & & & $\begin{array}{l}\text { protein and energy equivalent basis), } \\
\text { tallow (canola oil on mass basis)), mass } \\
\text { allocation for meat and hides (8.8-11\% } \\
\text { hides by mass) } \\
\text { - LW to boned retail meat yield was 57.1- } \\
60.7 \% \text { for SW and NE supply chains }\end{array}$ & $\begin{array}{l}\text { - Economic allocation resulted in } 7 \%, 8 \% \text { and } 15 \% \text { higher } \\
\text { burdens being applied to main product (meat) for ghg, energy } \\
\text { and water impact categories respectively when compared to } \\
\text { system expansion for minor byproducts } \\
\text { - Did not specify emissions from meat processing }\end{array}$ \\
\hline $\begin{array}{l}\text { SG Wiedemann, } \\
\text { EJ McGahan, CM } \\
\text { Murphy, M-J Yan, } \\
\text { B Henry, G. } \\
\text { Thoma, S } \\
\text { Ledgard. } \\
\text { Meat \& Livestock } \\
\text { Australia Project } \\
\text { B.CCH.2072 } \\
\text { (Beef), published } \\
\text { in } \\
\text { "Environmental } \\
\text { impacts and } \\
\text { resource use of } \\
\text { Australian beef }\end{array}$ & 2014 & $\begin{array}{l}\text { Beef - } \\
2 \text { regions in } \\
\text { eastern } \\
\text { Australia } \\
\text { (southern and } \\
\text { central QLD, } \\
25 \% \text { of } \\
\text { Australian } \\
\text { beef herd, and } \\
\text { north and } \\
\text { north western } \\
\text { NSW, } 10 \% \text { of } \\
\text { Australian } \\
\text { beef herd), } \\
\text { exported to }\end{array}$ & $\begin{array}{l}\text {-Attributional LCA } \\
\text {-15 case study farms and feedlots across } \\
2 \text { regions for the period 2007-2010, } \\
\text { augmented with regional survey data for } \\
\text { farms from the Australian Bureau of } \\
\text { Agricultural and Resource Economics } \\
\text { and Sciences (ABARES) (115 beef } \\
\text { producers) for the period } 2005-2010 \text {, } \\
\text { regional average farms modelled from } \\
\text { the ABARES data, and } 2 \text { QLD meat } \\
\text { processing plants supplemented by } 2011 \\
\text { industry resource survey (GHD, 2011), } \\
\text { including wastewater methane } \\
\text { emissions (inventory for t CW of: } 318 \\
\text { kWh, } 1230 \text { MJ natural gas, } 693 \mathrm{MJ} \text { coal, }\end{array}$ & $\begin{array}{l}\text { - } 7 \text { Impact categories - resource use, consumptive and stress } \\
\text { weighted water use, total and arable land occupation, human } \\
\text { edible protein efficiency, greenhouse gas emissions, all } \\
\text { reported per kg boneless beef. } \\
\text { - Resource use - ranged from } 24.2 \mathrm{MJ} \text { (QLD grass) to } 44.3 \mathrm{MJ} \\
\text { (NSW LF), approximately } 8.6 \mathrm{MJ} \text { from meat processing (19- } \\
35 \% \text { ) } \\
\text { - Consumptive water use - ranged from } 410.2 \mathrm{~L} \text { (NSW LF) to } \\
640.3 \mathrm{~L} \text { (QLD grass), approximately } 12.6 \mathrm{~L} \text { from meat } \\
\text { processing ( } 2 \text { - } 3 \% \text { ) } \\
\text { - Stressed water use - ranged from } 40 \mathrm{~L} \mathrm{H} \mathrm{H}_{2} \mathrm{O} \text {-e (NSW grass) to } \\
234 \mathrm{~L} \mathrm{H} \mathrm{H}_{2} \text {-e (QLD grass) } \\
\text {-Arable land occupation (cultivated) - ranged from } 0 \mathrm{~m}^{2} \text { (QLD } \\
\text { grass) to } 28.7 \mathrm{~m}^{2} \text { (NSW LF), which equates to } 0 \% \text { and } 29 \% \text { of } \\
\text { total land use }\end{array}$ \\
\hline
\end{tabular}




\begin{tabular}{|c|c|c|c|c|}
\hline Authors & Year & Sector & Details & Results \\
\hline $\begin{array}{l}\text { and lamb } \\
\text { exported to the } \\
\text { USA determined } \\
\text { using life cycle } \\
\text { assessment", } \\
\text { Journal of } \\
\text { Cleaner } \\
\text { Production } 94 \\
\text { (2015) 67-75. }\end{array}$ & & $\begin{array}{c}\text { USA } \\
\text { (Philadelphia } \\
\text { and Los } \\
\text { Angeles), NSW } \\
\text { and QLD grass } \\
\text { fed, NSW and } \\
\text { QLD mid fed } \\
\text { grain (MF = } \\
\text { 115 days), and } \\
\text { NSW long fed } \\
\text { grain (LF = 330 } \\
\text { days), } \\
\text { predominantly } \\
\text { Angus and } \\
\text { Wagyu for } \\
\text { USA } \\
\text { restaurant } \\
\text { trade }\end{array}$ & $\begin{array}{l}83 \mathrm{MJ} \text { LPG, } 40 \mathrm{MJ} \text { diesel and 7MJ petrol, } \\
8.7 \mathrm{~kL} \text { water use) } \\
\text { - System boundary from farm to } \\
\text { wholesale distribution (cold-storage } \\
\text { warehouse) in USA } \\
\text { - Functional units - kg boneless, retail } \\
\text { ready beef } \\
\text { - } \mathrm{CO}_{2-\mathrm{e}} \text { emissions from land use (LU) and } \\
\text { direct land use change (dLUC) estimated } \\
\text { from average data) for regional average } \\
\text { farms, but excluded for case study } \\
\text { farms. Three cases for land use/dLUC } \\
\text { associated with feed grain production } \\
\text { were included for feedlot. Two cases } \\
\text { modelled for net emissions from } \\
\text { vegetation clearing and regrowth } \\
\text { - System expansion to handle minor } \\
\text { byproducts (pet food, blood, meat and } \\
\text { bone meal (soymeal and sorghum on } \\
\text { protein and energy equivalent basis), } \\
\text { tallow (canola oil), biophysical }\end{array}$ & 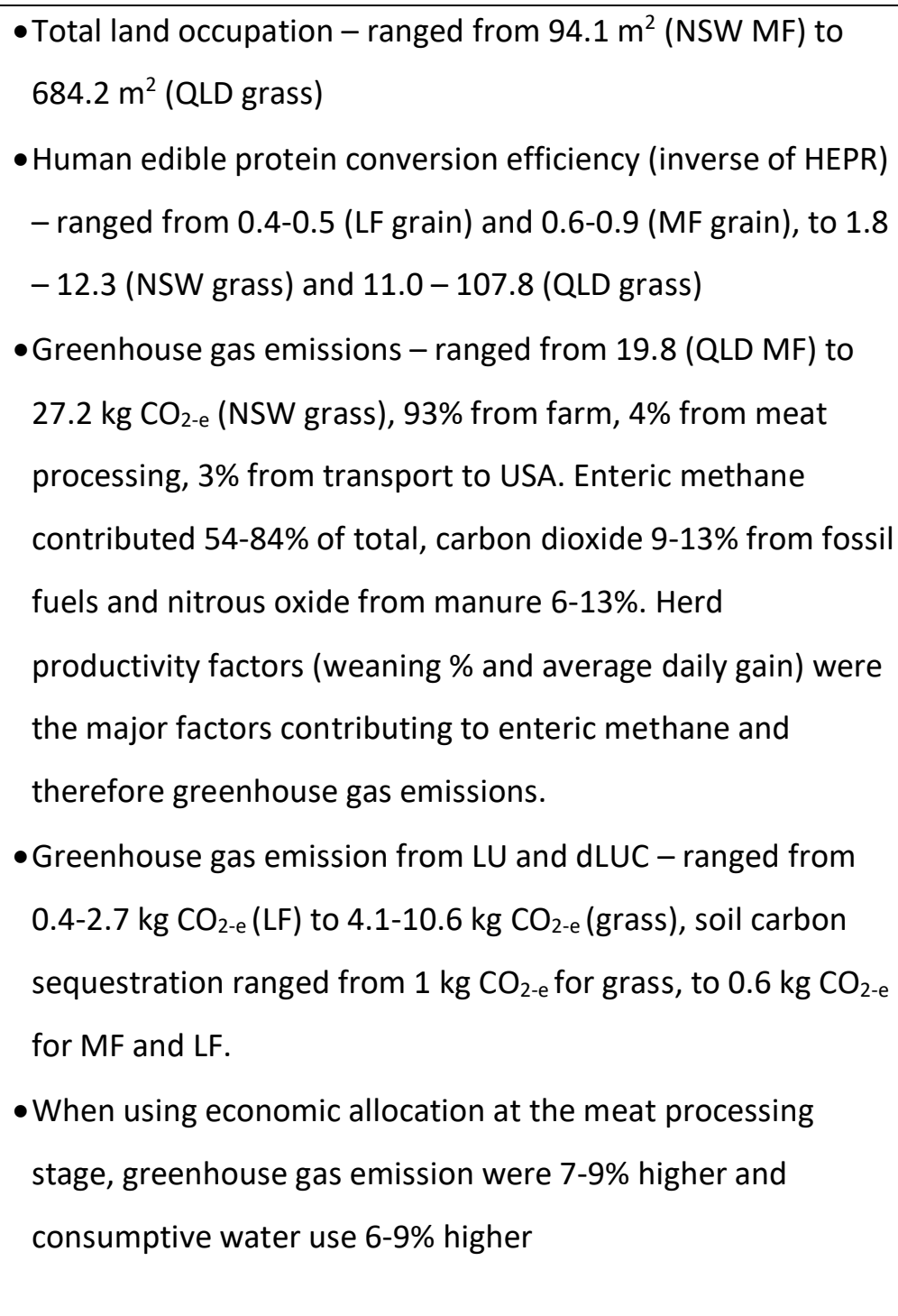 \\
\hline
\end{tabular}




\begin{tabular}{|c|c|c|c|c|}
\hline Authors & Year & Sector & Details & Results \\
\hline & & & $\begin{array}{l}\text { allocation for meat and hides based on } \\
\text { protein content in products } \\
\text { - Carcase yield of } 53 \% \text { ( } 55 \% \text { dressing (LW } \\
\text { to } \mathrm{HSCW} \text { ), chilling losses of } 3 \% \text { (HSCW to } \\
\mathrm{CW} \text { ) and retail yield (CW to retail } \\
\text { portions) of } 70 \% \text {, edible fraction of retail } \\
\text { portions } 95 \%\end{array}$ & \\
\hline $\begin{array}{l}\text { SG Wiedemann, } \\
\text { EJ McGahan, CM } \\
\text { Murphy, M-J Yan, } \\
\text { B Henry, G. } \\
\text { Thoma, S } \\
\text { Ledgard. } \\
\text { Meat \& Livestock } \\
\text { Australia Project } \\
\text { B.CCH.2072 } \\
\text { (Lamb), } \\
\text { published in } \\
\text { “Environmental } \\
\text { impacts and } \\
\text { resource use of }\end{array}$ & 2015 & $\begin{array}{l}\text { Lamb - } \\
\text { from } 3 \\
\text { production } \\
\text { regions in } \\
\text { south-eastern } \\
\text { Australia, } \\
\text { Victoria (VIC, } \\
21 \% \text { of sheep } \\
\text { flock), south- } \\
\text { eastern South } \\
\text { Australia (SA, } \\
\text { 16\% of sheep } \\
\text { flock) and } \\
\text { northern and }\end{array}$ & $\begin{array}{l}\text {-Attributional LCA } \\
\text {-6 supply chains modelled - } 10 \text { case study } \\
\text { farms (CSF) in each of the } 3 \text { regions over } \\
\text { a 1-2+ year period, regional average } \\
\text { farms (RAF) from industry survey of } \\
\text { specialist lamb producers for each } \\
\text { region from the Australian Bureau of } \\
\text { Agricultural and Resource Economics } \\
\text { and Sciences (ABARES) for the period } \\
2006-2010, \text { one lamb feedlot in VIC, data } \\
\text { for } 3 \text { meat processing plants from } 2011 \\
\text { industry resource survey using data from } \\
2008-09 \text { (GHD, 2011), including } \\
\text { wastewater methane emissions }\end{array}$ & 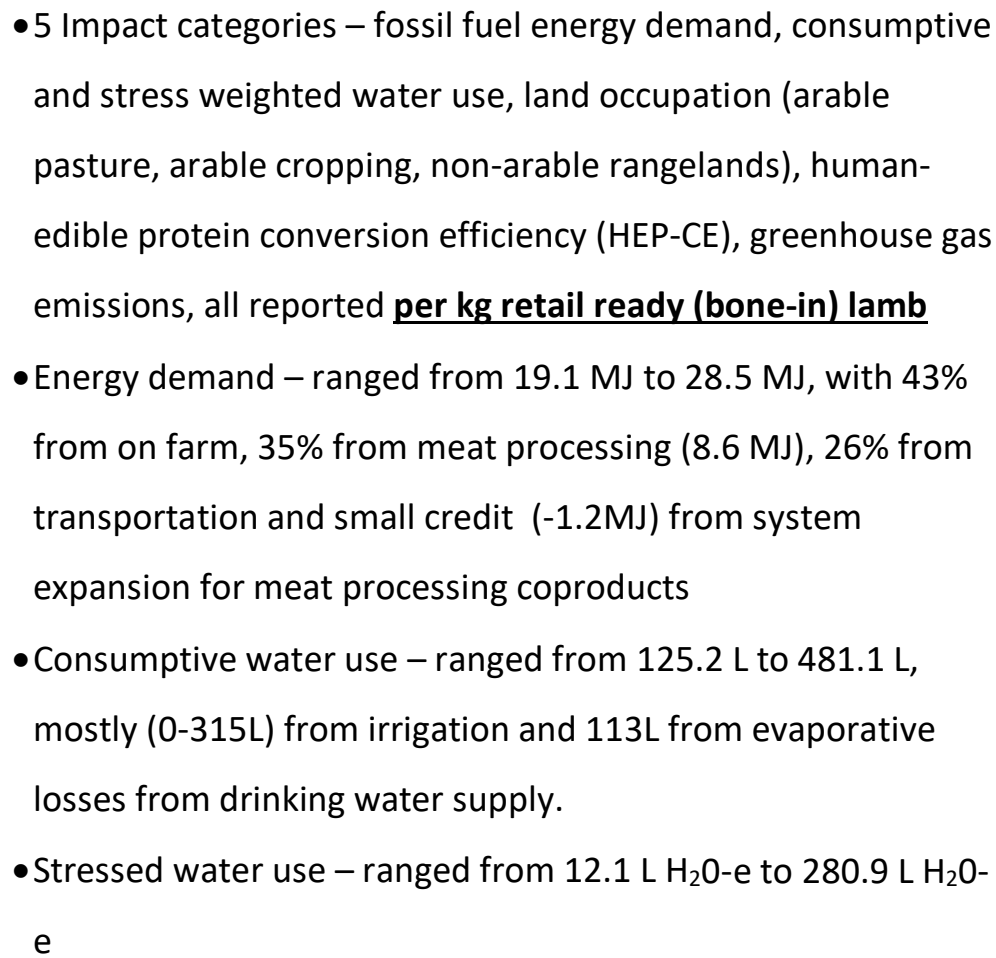 \\
\hline
\end{tabular}




\begin{tabular}{|c|c|c|c|c|}
\hline Authors & Year & Sector & Details & Results \\
\hline $\begin{array}{l}\text { Australian beef } \\
\text { and lamb } \\
\text { exported to the } \\
\text { USA determined } \\
\text { using life cycle } \\
\text { assessment", } \\
\text { Journal of } \\
\text { Cleaner } \\
\text { Production } 94 \\
\text { (2015) 67-75. }\end{array}$ & & $\begin{array}{c}\text { southern New } \\
\text { South Wales } \\
\text { (NSW, 37\% of } \\
\text { Australian } \\
\text { flock), mostly } \\
\text { pasture fed, } \\
\text { 15\% of NSW } \\
\text { and SA grain } \\
\text { finished for } 46 \\
\text { days (Meat \& } \\
\text { Livestock } \\
\text { Australia, } \\
\text { 2017). Export } \\
\text { by ship to USA } \\
\text { ports of } \\
\text { Philadelphia } \\
\text { and Los } \\
\text { Angeles. }\end{array}$ & $\begin{array}{l}\text { (assumes inventory for t CW of: 1,185 } \\
\text { kWh, } 2346 \text { MJ natural gas, } 533 \text { MJ LPG, } \\
19 \text { MJ diesel and 14MJ petrol, } 6.0 \mathrm{~kL} \\
\text { water use) } \\
\text { - System boundary from farm to } \\
\text { wholesale distribution (cold-storage } \\
\text { warehouse) in USA } \\
\text { - Functional units - kg retail ready (bone- } \\
\text { in) lamb at the cold-storage warehouse } \\
\text { in the USA } \\
\text { - CO }{ }_{2-\mathrm{e}} \text { emissions from land use (LU) and } \\
\text { direct land use change (dLUC) estimated } \\
\text { for two cases, with and without soil } \\
\text { carbon sequestration } \\
\text { - Biophysical allocation between wool } \\
\text { and meat based on biophysical (protein } \\
\text { content), biophysical allocation for } \\
\text { meat and skins based on mass of } \\
\text { products system expansion to handle } \\
\text { minor byproducts (pet food, blood, meat } \\
\text { and bone meal (soymeal using economic }\end{array}$ & $\begin{array}{l}\text { - Arable land occupation (cultivated) - averaged } 2.1 \mathrm{~m}^{2} \\
\text { - Total greenhouse gas emissions - ranged from } 13.4 \text { to } 16.1 \mathrm{~kg} \\
\mathrm{CO}_{2-\mathrm{e}}, 90 \% \text { from farms, } 72-79 \% \text { of which are from enteric } \\
\text { methane from sheep. Meat processing (5.5-6.6\% of total) and } \\
\text { transport were second and third largest contributors. } \\
\text { - Greenhouse emissions from land use and land use change } \\
\text { was } 0.4 \text { if soil carbon sequestration was assumed to be zero, } \\
\text { or -0.8 to -4 when soil carbon sequestration from fertilised } \\
\text { pastures was included } \\
\text { - Note -the } 2008 / 2009 \text { financial year data used in the GDH } \\
2011 \text { report is much higher than the subsequent figures using } \\
\text { data from the } 2013 / 2014 \text { financial year (Ridoutt et al., } 2015 \text { ), } \\
\text { possibly due to the inclusion of the Fletchers Dubbo wool } \\
\text { scour which closed in December } 2010 \text {. } \\
\text { - Sensitivity case using economic allocation for wool/meat and } \\
\text { meat/skins increased ghg by } 9 \% \text {, fossil energy by } 10 \% \text { and } \\
\text { consumptive water by } 8 \%\end{array}$ \\
\hline
\end{tabular}




\begin{tabular}{|c|c|c|c|c|}
\hline Authors & Year & Sector & Details & Results \\
\hline & & & $\begin{array}{l}\text { allocation, assuming } 10 \% \text { domestic } \\
\text { production, } 40 \% \text { import from USA and } \\
50 \% \text { import from Argentina), tallow } \\
\text { (palm oil from Malaysia). } \\
\text { - Carcass yield } 45 \% \text { (Dressing percentage } \\
\text { of } 47 \% \text { (LW to HSCW), chilling losses of } \\
4 \% \text { (HSCW to CW)), retail yield (bone-in } \\
\text { retail cuts from cold carcase weight) of } \\
88 \% \text { after removal of fat trim }\end{array}$ & \\
\hline $\begin{array}{l}\text { S. G. } \\
\text { Wiedemann, E. J. } \\
\text { McGahan, C. M. } \\
\text { Murphy, } \\
\text { published as } \\
\text { “Environmental } \\
\text { impacts and } \\
\text { resource use } \\
\text { from Australian } \\
\text { pork production } \\
\text { assessed using } \\
\text { life-cycle }\end{array}$ & $\begin{array}{l}2016- \\
2018\end{array}$ & $\begin{array}{l}\text { Pork } \\
\text { (6 case study } \\
\text { supply chains } \\
\text { and the } \\
\text { national herd, } \\
4 \text { major } \\
\text { production } \\
\text { regions } \\
\text { (Queensland } \\
\text { (QLD), New } \\
\text { South Wales } \\
\text { (NSW), }\end{array}$ & $\begin{array}{l}\text { - Attributional LCA } \\
\text { - Included } 14 \text { case study farms in } 4 \\
\text { regions, representing } 6 \text { case study } \\
\text { supply chains for minimum } 12 \text { month } \\
\text { period in the years 2010-2011 and the } \\
\text { national herd (based on national survey } \\
\text { for 2010). Six supply chains are QLD } \\
\text { small-medium conventional, QLD large } \\
\text { conventional, NSW conventional housing } \\
\text { for breeding pigs and deep litter housing } \\
\text { for grower-finisher pigs, VIC large } \\
\text { conventional, WA large conventional }\end{array}$ & $\begin{array}{l}\text { - Impact categories - greenhouse gas emissions (including land } \\
\text { use and direct land use change), fossil fuel energy demand, } \\
\text { consumptive and stress weighted water use, land occupation } \\
\text { (arable pasture, arable cropping, non-arable rangelands), all } \\
\text { reported per kg wholesale pork (chilled, bone-in) } \\
\text { - Greenhouse gas emissions - } 6.36 \mathrm{~kg} \mathrm{CO} \mathrm{CO}_{2-\mathrm{e}}, 50 \% \text { from manure } \\
\text { management, } 27 \% \text { from fed production, } 8 \% \text { from meat } \\
\text { processing. LU and dLUC only had a minor (6\%) impact, } \\
\text { mostly due to dLUC soymeal production in South America } \\
\text { being higher than sequestration in Australian arable } \\
\text { cropland. Capture of methane from manure management } \\
\text { and use in cogeneration plant resulted in 31-64\% reduction in }\end{array}$ \\
\hline
\end{tabular}




\begin{tabular}{|c|c|c|c|c|}
\hline Authors & Year & Sector & Details & Results \\
\hline $\begin{array}{l}\text { assessment. } 1 . \\
\text { Greenhouse gas } \\
\text { emissions" in } \\
\text { Animal } \\
\text { Production } \\
\text { Science, 2016, } \\
\text { 56, 1418-1431 } \\
\text { AND } \\
\text { "Environmental } \\
\text { impacts and } \\
\text { resource use } \\
\text { from Australian } \\
\text { pork production } \\
\text { determined using } \\
\text { life cycle } \\
\text { assessment. } 2 . \\
\text { Energy, water } \\
\text { and land } \\
\text { occupation” in } \\
\text { Animal } \\
\text { Production } \\
\text { ing }\end{array}$ & & $\begin{array}{c}\text { Western } \\
\text { Australia (WA) } \\
\text { and Victoria } \\
(\mathrm{VIC})) .\end{array}$ & $\begin{array}{l}\text { and WA outdoor housing for breeding } \\
\text { pigs and deep litter for grower-finisher } \\
\text { pigs. Whole herd Feed Conversion Ratio } \\
\text { (FCR) ranged from 2.4-3.2, national } \\
\text { average } 3.1 \text {. } \\
\text { - data for } 4 \text { meat processing plants over a } \\
12 \text { month period, including wastewater } \\
\text { methane emissions (assumes inventory } \\
\text { for t chilled pork of: } 252 \text { kWh, } 5.9 \text { m }{ }^{3} \\
\text { natural gas, } 15.5 \text { L LPG, } 11.3 \text { kg coal, } \\
\text { 0.49 L diesel and } 0.25 \text { L petrol, water use } \\
\text { not stated separately } \\
\text { - System boundary from farm to cold } \\
\text { storage unit where pork is stored prior } \\
\text { to wholesale distribution, includes } \\
\text { livestock transport from farm to } \\
\text { processing plant } \\
\text { (LW) at the farm gate and } 1 \text { kg of } \\
\text { for packaging and distribution }\end{array}$ & $\begin{array}{l}\text { greenhouse emissions. Switching from conventional housing } \\
\text { to deep litter resulting in } 30 \% \text { lower emissions. Higher } \\
\text { emissions than European studies due to emissions from } \\
\text { manure management. Feed Conversion Ratio accounted for } \\
88 \% \text { of the variation in ghg intensity between sites. } \\
\text { - Fossil fuel energy demand - } 27 \text { MJ, with } 47 \% \text { from feed } \\
\text { production, } 23 \% \text { from piggery energy use (mostly for } \\
\text { cooling), } 16 \% \text { from fed milling and } 14 \% \text { from meat } \\
\text { processing. Manure use for biogas production could reduce } \\
\text { energy demand by } 25 \% \text {. } \\
\text { - Consumptive water use - ranged from } 184 \text { L, mostly ( } 74 \% \text { ) } \\
\text { from irrigation for feed production, followed by farm (animal) } \\
\text { consumption ( } 29 \% \text { ) and } 6 \% \text { at meat processing stage. } \\
\text { Potential to improve water use efficiency by using piggery } \\
\text { effluent for crop production, to reduce fresh water and } \\
\text { synthetic fertiliser use } \\
\text { - Stressed water use - } 172 \mathrm{~L} \mathrm{H}_{2} 0 \text {-e, regional water stress has } \\
\text { feed production, higher than European values due to lower } \\
\text { grain yolds }\end{array}$ \\
\hline
\end{tabular}




\begin{tabular}{|c|c|c|c|c|}
\hline Authors & Year & Sector & Details & Results \\
\hline $\begin{array}{l}\text { Science, 2018, } \\
\text { 58, 1153-1163. } \\
\text { HEPR reported in } \\
\text { Wiedemann } 2018 \\
\text { PhD thesis } \\
\text { (Wiedemann, } \\
\text { 2018). }\end{array}$ & & & $\begin{array}{l}\text { - } \mathrm{CO}_{2} \text {-e emissions from direct land use } \\
\text { change (dLUC) for conversion of forest } \\
\text { to crop land and land use (LU) } \mathrm{CO}_{2} \text {-e } \\
\text { sequestration due to improved cropping } \\
\text { were estimated from national inventory } \\
\text { data for the period 1990-2010, net result } \\
\text { was annualised sequestration of } 2 \mathrm{~kg} \\
\mathrm{CO}_{2} \text {-e /ha } \\
\text {-Allocation used with manure, assume } \\
30 \% \text { of nutrient content is used as cereal } \\
\text { crop fertiliser (reducing industrial } \\
\text { fertiliser use), economic allocation } \\
\text { between meat and pet food, renderable } \\
\text { products considered a residue and no } \\
\text { impacts allocated to these products ie } \\
\text { no allocation to tallow and meal. } \\
\text {-Dressing percentage of } 76 \% \text { (LW to } \\
\text { HSCW), chilling loss } 4 \% \text { (HSCW to CW), } \\
\text { retail yield } 77 \% \text { (CW to retail portions), } \\
\text { edible yield/fraction of retail portions } \\
85 \%\end{array}$ & $\begin{array}{l}\text { - Sensitivity - feed use was the source of the greatest impacts } \\
\text { in most impact categories, diets with lower amounts of } \\
\text { soymeal had lower impacts, other Australian grown grains } \\
\text { (wheat, barley, sorghum) were relatively similar. Stressed } \\
\text { water use is very dependant on irrigation for grain } \\
\text { production, and arable land use was very dependent on grain } \\
\text { yield, which can vary significantly between years (eg wheat } \\
\text { yields were } 2.0 \text { and } 0.9 \text { t/ha for } 2006 \text { and } 2007 \text { respectively). } \\
\text { Inter annual rainfall variation, and the impact on land and } \\
\text { water use, mans that benchmarking needs to be updated } \\
\text { frequent and/or longer averaging periods used to produce } \\
\text { more stable results. }\end{array}$ \\
\hline
\end{tabular}



data unless otherwise specified)

\begin{tabular}{|c|c|c|c|}
\hline Flow & Unit & Amount & Comment \\
\hline \multicolumn{4}{|c|}{ 1. Livestock, consumables $\&$ waste } \\
\hline \multicolumn{4}{|c|}{1.1 Inputs } \\
\hline Cleaning chemicals $^{1}$ & $\mathrm{~kg}$ & 1.3 & \\
\hline Wastewater chemicals & $\mathrm{kg}$ & 0.2 & \\
\hline Live weight of livestock & $\mathrm{t}$ & 2 & \\
\hline Oils \& lubes ${ }^{1}$ & $\mathrm{~kg}$ & 0.18 & \\
\hline Transport-local & $\mathrm{tkm}$ & 4.75 & Includes chemicals to site, waste to landfill \\
\hline Transport-national & $\mathrm{tkm}$ & 1000.76 & Includes livestock to site, chemicals etc \\
\hline \multicolumn{4}{|l|}{1.2 Outputs } \\
\hline Solid waste to landfill & $\mathrm{t}$ & 0.03 & Excludes packaging \\
\hline $\mathrm{N}$ in manure & $\mathrm{kg}$ & 0.0073 & \\
\hline $\mathrm{P}$ in manure & $\mathrm{kg}$ & 0.0041 & \\
\hline Paunch & $\mathrm{t}$ & 0.081 & Used as soil conditioner \\
\hline
\end{tabular}

\section{Energy systems}

\begin{tabular}{|c|c|c|c|}
\hline \multicolumn{4}{|l|}{2.1 Inputs } \\
\hline Boiler ash & $\mathrm{t}$ & -0.007 & Included as a credit, natural aggregate \\
\hline Coal & $\mathrm{t}$ & 0.10 & \\
\hline Electricity & kWh & 104.94 & \\
\hline Diesel - backup boiler & MJ & 276.19 & \\
\hline LPG & MJ & 4.63 & Used in water heater, laundry, kitchen etc \\
\hline Boiler - scale inhibitor & $\mathrm{kg}$ & 0.00031 & Sodium carbonate \\
\hline Boiler - softener & $\mathrm{kg}$ & 0.21 & Sodium chloride \\
\hline Boiler - scale inhibitor & $\mathrm{kg}$ & 0.00008 & Sodium hydroxide \\
\hline Boiler - tannin & $\mathrm{kg}$ & 0.002 & \\
\hline Transport - local & $\mathrm{tkm}$ & 5.25 & \\
\hline Transport - national & $\mathrm{tkm}$ & 61.31 & \\
\hline Diesel - current usage & $\mathrm{tkm}$ & 63.60 & \\
\hline Petrol - current usage & $\mathrm{km}$ & 11.84 & \\
\hline \multicolumn{4}{|l|}{2.2 Outputs } \\
\hline Methane from onsite ponds & $\mathrm{t}$ & 0.01685 & Based on estimate from NGER \\
\hline Tallow & $\mathrm{t}$ & 0.12 & $\begin{array}{l}\text { Included here to enable use in parameterised } \\
\text { model }\end{array}$ \\
\hline
\end{tabular}

\section{Packaging ${ }^{1,2}$}

3.1 Inputs

Cardboard Vacuum bags

Polyethylene plastic

Polypropylene plastic Strapping (polypropylene) Paper Other plastics - PVC wrap Stockinette - cotton Hessian Transport - national

\begin{tabular}{|c|c|l|}
\hline $\mathrm{kg}$ & 31 & \\
\hline $\mathrm{kg}$ & 2.56 & $\begin{array}{l}\text { Assumed to be 50\% polyamide, 50\% } \\
\text { polyethylene, 9\% wastage }\end{array}$ \\
\hline $\mathrm{kg}$ & 2.09 & 5\% wastage \\
\hline $\mathrm{kg}$ & 0.09 & Assumed 5\% wastage, plastic trays etc \\
\hline $\mathrm{kg}$ & 0.84 & $2 \%$ wastage \\
\hline $\mathrm{kg}$ & 0.92 & Assumed 5\% wastage, used for labels \\
\hline $\mathrm{kg}$ & 0.06 & $13 \%$ wastage \\
\hline $\mathrm{kg}$ & 0.36 & Assume 5\% wastage \\
\hline $\mathrm{kg}$ & 0.4 & Assumed 5\% wastage, modelled as jute \\
\hline & & Materials into local depot \\
\hline
\end{tabular}


Using a gate-to-gate LCA to apply circular economy principles to a food processing SME

\begin{tabular}{|c|c|c|c|}
\hline Flow & Unit & Amount & Comment \\
\hline Transport - local & & & Materials in + waste to landfill \\
\hline \multicolumn{4}{|l|}{3.2 Outputs - waste to landfill } \\
\hline Cardboard & $\mathrm{kg}$ & 0.62 & \\
\hline Plastic mix & $\mathrm{kg}$ & 0.34 & \\
\hline Plastic-polypropylene & $\mathrm{kg}$ & 0.02 & \\
\hline \multicolumn{4}{|l|}{ 4. Pest control } \\
\hline \multicolumn{4}{|l|}{4.1 Inputs } \\
\hline Fipronil & $\mathrm{kg}$ & 0.0000012 & \multirow{3}{*}{$\begin{array}{l}\text { All modelled as output flows to agricultural } \\
\text { soils }\end{array}$} \\
\hline Bifenthrin & $\mathrm{kg}$ & 0.0005 & \\
\hline Permethrin & $\mathrm{kg}$ & 0.00000245 & \\
\hline Transport - national & $\mathrm{tkm}$ & 0.001 & \\
\hline Transport - local & tkm & 0.003 & \\
\hline \multicolumn{4}{|l|}{ 5. Refrigerants } \\
\hline \multicolumn{4}{|l|}{5.1 Inputs } \\
\hline R134a equivalent & $\mathrm{kg}$ & 0.0043 & \\
\hline Transport - national & $\mathrm{tkm}$ & 0.9 & \\
\hline Transport - local & tkm & 0.3 & \\
\hline \multicolumn{4}{|l|}{5.2 Outputs } \\
\hline R12 (CFC-12) & $\mathrm{kg}$ & 0.0002 & \multirow{5}{*}{$\begin{array}{l}\text { Refrigerant change estimated as } 1.5 \mathrm{~kg} / \mathrm{kW} \\
\text { load from wattage on installed equipment } \\
\text { list, } 10 \% \text { annual loss rate assumed }{ }^{3} \text {, modelled } \\
\text { as elementary flow to air/ low population } \\
\text { density }\end{array}$} \\
\hline R22 (HCFC-22) & $\mathrm{kg}$ & 0.001 & \\
\hline R134a (HFC-134a) & $\mathrm{kg}$ & 0.0003 & \\
\hline R125 (HFC-125) & $\mathrm{kg}$ & 0.00008 & \\
\hline R143 (HFC-143) & $\mathrm{kg}$ & 0.00009 & \\
\hline \multicolumn{4}{|l|}{ 6. Skins treating } \\
\hline \multicolumn{4}{|l|}{6.1 Inputs } \\
\hline $\begin{array}{l}\text { 5-Chloro-2-methyl-4- } \\
\text { isothiazolin-3-one + 2-Methyl- } \\
\text { 4-isothiazolin-3-one }\end{array}$ & $\mathrm{kg}$ & 0.022 & $\begin{array}{l}\text { benzo[thia]diazole-compound ecoinvent flow } \\
\text { used }\end{array}$ \\
\hline Boric acid & $\mathrm{kg}$ & 0.34 & \\
\hline Sodium chloride & $\mathrm{kg}$ & 29.63 & \\
\hline Sodium fluoride & $\mathrm{kg}$ & 0.34 & \\
\hline Untreated hides & $\mathrm{t}$ & 0.18 & \\
\hline Transport-roads - national & tkm & 139.65 & \\
\hline Transport - ship & $\mathrm{tkm}$ & 1,420 & \\
\hline \multicolumn{4}{|l|}{6.2 Outputs } \\
\hline Etridiazole & $\mathrm{kg}$ & 0.011 & $\begin{array}{l}\text { Ecoinvent flow used, } 50 \% \text { to ag soil, rest with } \\
\text { effluent }\end{array}$ \\
\hline Treated hides & $\mathrm{t}$ & 0.14 & \\
\hline Hide water & $\mathrm{t}$ & 0.04 & \\
\hline \multicolumn{4}{|c|}{ 7. Water use and wastewater treatment } \\
\hline \multicolumn{4}{|c|}{\begin{tabular}{l|l|l}
7.1 Inputs & \\
\end{tabular}} \\
\hline Fresh water consumption & $\mathrm{m}^{3}$ & 3.7 & \\
\hline \multicolumn{4}{|l|}{7.2 Outputs } \\
\hline Treated effluent & $\mathrm{m}^{3}$ & 3.0 & \\
\hline Wastewater calcium & $\mathrm{kg}$ & 0.1 & \\
\hline Wastewater magnesium & $\mathrm{kg}$ & 0.05 & \\
\hline Wastewater nitrogen & $\mathrm{kg}$ & 1.0 & \\
\hline Wastewater phosphorus & $\mathrm{kg}$ & 0.2 & \\
\hline
\end{tabular}




\begin{tabular}{|l|c|c|l|}
\hline Flow & Unit & Amount & Comment \\
\hline Wastewater potassium & $\mathrm{kg}$ & 0.3 & \\
\hline Wastewater sodium chloride & $\mathrm{kg}$ & 1.3 & \\
\hline Water evaporation & $\mathrm{t}$ & 0.23 & From tallow, meal, chillers losses \\
\hline
\end{tabular}

8. Whole plant

8.1 Inputs

\begin{tabular}{|l|c|c|l|}
\hline Transport - national & $\mathrm{tkm}$ & 140 & \\
\hline Transport - sea & $\mathrm{tkm}$ & 1,438 & \\
\hline 8.2 Outputs & & & \\
\hline Edible offal & $\mathrm{t}$ & 0.12 & \\
\hline Meat & $\mathrm{t}$ & 1 & \\
\hline Meal & $\mathrm{t}$ & 0.11 & \\
\hline
\end{tabular}

Notes: 1) (Pagan et al., 2002), 2) (Coopers and Lybrand Consultants, 1996), 3) (Emerson Climate

Technologies, 2010b)

- Manure - market for solid cattle manure

\begin{tabular}{|c|c|}
\hline Scenario & Details \\
\hline $\begin{array}{l}\text { Efficiency } \\
\text { (EFF) }\end{array}$ & $\begin{array}{l}\text { - } 15 \mathrm{~kW} \text { solar PV - average daily production assumed to be the same for } \\
\text { Coffs Harbour (3.95 kWh/kW.day) (Clean Energy Council, 2017) } \\
\text { - Wind }-25 \mathrm{~kW}\end{array}$ \\
\hline Tallow (TAL) & $\begin{array}{l}\text { - Life Cycle Inventory data taken from (Dufour and Iribarren, 2012), } \\
\text { values for rendered beef tallow, included in all subsequent scenarios } \\
\text { - Ecoinvent process modified using emissions data from Australian NGER } \\
\text { regulations for } \\
\text { o Biodiesel use in site transport fleet } \\
\text { o Tallow combustion to produce electricity } \\
\text { o Tallow combustion to produce thermal energy } \\
\text { - No tallow remaining to be sold, some coal still required for thermal } \\
\text { - energy requirements } \\
\text { Glycerine from biodiesel production assumed to be sold offsite }\end{array}$ \\
\hline
\end{tabular}




\begin{tabular}{|c|c|c|c|c|c|}
\hline Scenario & \multicolumn{5}{|l|}{ Details } \\
\hline Biogas (BGS) & \multicolumn{5}{|c|}{$\begin{array}{l}\text { - Life Cycle Inventory data taken from (Poeschl et al., 2012), values for } \\
\text { upgrading biogas to biomethane for substituting natural gas ( } 0.38 \\
\mathrm{kWh}_{\mathrm{el}} / \mathrm{m}^{3} \text { biogas, } 0.1 \mathrm{kWh} \text { th } / \mathrm{m}^{3} \text { biogas). } \\
\text { - Glycerine assumed to be discharged to the anaerobic pond to increase } \\
\text { biogas production, rather than being sold offsite, for this and } \\
\text { subsequent process. NGER values used to estimate biogas production, } \\
0.8 \text { fraction degraded anaerobically, density } 1.25 \mathrm{~kg} / \mathrm{L} \text {, average COD } \\
1,262,500 \mathrm{mg} / \mathrm{L} \text {. } \\
\text { - Ecoinvent process modified using emissions data from Australian NGER } \\
\text { regulations for biogas combustion in gas engine }\end{array}$} \\
\hline Biomass (BM) & \multicolumn{5}{|c|}{$\begin{array}{l}\text { - Life Cycle Inventory data taken from (Yanagida et al., 2011), diesel fuel } \\
\text { use for transport converted into tkm at given fuel efficiency, included in } \\
\text { existing flows. Fertiliser use modelled as credit from all nutrients } \\
\text { available from treated effluent from site. } \\
\text { - Ecoinvent process used for biomass used for thermal energy } \\
\text { production, with land use removed from final number for agricultural } \\
\text { land use }\end{array}$} \\
\hline \multirow[t]{6}{*}{$\begin{array}{l}\text { Biomass land } \\
\text { area } \\
\text { calculations }\end{array}$} & \multicolumn{5}{|c|}{$\begin{array}{l}\text { - Values used - biomass production }=30 \mathrm{~m}^{3} / \mathrm{ha} / \text { year } \times 265 \mathrm{~kg} / \mathrm{m}^{3} \text { density } \\
\text { x } 10.4 \mathrm{GJ} / \mathrm{t}=83 \mathrm{GJ} \text { biomass/ha/year } \\
\text { - Plant thermal energy consumption }=2,739 \mathrm{MJ} / \mathrm{t} \mathrm{HSCW} \rightarrow 0.033 \\
\text { ha/year } \\
\text { - Plant total energy consumption }=3,326 \mathrm{MJ} / \mathrm{t} \mathrm{HSCW} \text { at } 20 \% \text { efficiency } \\
\text { of conversion }=16,630 \mathrm{MJ} / \mathrm{t} \mathrm{HSCW} \rightarrow 0.2 \mathrm{ha} / \text { year } \\
\text { - Land area for livestock production derived from (Wiedemann et al., } \\
\text { 2015b) }\end{array}$} \\
\hline & ha/t HSCW & Beef grass & Beef MF & Beef LF & Lamb \\
\hline & non arable & 29.3 & 21.8 & 11.6 & 21.4 \\
\hline & arable pasture & 1.5 & 1.1 & 0.6 & 1.1 \\
\hline & arable crop & 0.2 & 1.2 & 2.1 & 0.2 \\
\hline & total & 31 & 24.1 & 14.3 & 22.7 \\
\hline
\end{tabular}

